\title{
Synthesis, Structure and Reductive Elimination Chemistry of Three-Coordinate Arylpalladium Amido Complexes
}

Makoto Yamashita and John F. Hartwig

Department of Chemistry, Yale University, New Haven, CT 06520-8107

\section{Supporting Information}

\section{Synthetic Procedures}

General Methods. ${ }^{1} \mathrm{H},{ }^{13} \mathrm{C}\left\{{ }^{1} \mathrm{H}\right\},{ }^{19} \mathrm{~F}\left\{{ }^{1} \mathrm{H}\right\}$, and ${ }^{31} \mathrm{P}\left\{{ }^{1} \mathrm{H}\right\}$ NMR spectra were recorded on 300,400 or $500 \mathrm{MHz}$ Spectrometers with residual protiated solvent, deuterated solvent, $\mathrm{C}_{6} \mathrm{~F}_{6}$, or $85 \% \quad \mathrm{H}_{3} \mathrm{PO}_{4}$ used as reference. Elemental analyses were performed by Robertson Microlabs, Inc., Madison, NJ. GC analyses were performed with an HP-1 methyl silicone column. Ether, toluene, tetrahydrofuran, and pentane were distilled from sodium/benzophenone. $\mathrm{Pd}(\mathrm{dba})_{2},{ }^{1}$ (TMEDA) $\mathrm{Pd}\left(\mathrm{C}_{6} \mathrm{H}_{4}-p-\mathrm{OMe}\right) \mathrm{I},{ }^{2}$ and $(\mathrm{DPPF}) \mathrm{Pd}\left(\mathrm{C}_{6} \mathrm{H}_{4}-p\right.$ $\mathrm{OMe}) \mathrm{I}^{3}$ were synthesized according to literature procedures.

Synthesis of $\left({ }^{t} \mathrm{Bu}_{3} \mathbf{P}\right) \mathbf{P d}\left(\mathrm{C}_{6} \mathrm{H}_{4}-p-\mathrm{OMe}\right) \mathrm{Br}$ (1a). In a drybox, $p$-bromoanisole (15.0 $\mathrm{mL}, 120 \mathrm{mmol})$ was added to a mixture of ${ }^{t} \mathrm{Bu}_{3} \mathrm{P}(445 \mathrm{mg}, 2.20 \mathrm{mmol})$ and $\mathrm{Pd}(\mathrm{dba})_{2}$ $(1.15 \mathrm{~g}, 2.00 \mathrm{mmol}),{ }^{1}$ and the resulting mixture was stirred at room temperature for 40 min. The reaction mixture was then added at room temperature to a flask containing vigorously stirred pentane $(100 \mathrm{~mL})$ to give a p brown-orange recipitate. The resulting suspension was filtered, and the solid was washed with pentane. The solid dissolved in THF, and the mixture was filtered. After concentration of the filtrate to about $20 \mathrm{~mL}$, the filtrate was added at room temperature to a flask containing vigorously stirred pentane $(150 \mathrm{~mL})$ to give an orange precipitate. The orange product was isolated by filtration (333 mg, 34\%). ${ }^{1} \mathrm{H} \mathrm{NMR}\left(\mathrm{C}_{6} \mathrm{D}_{6}, 400 \mathrm{MHz}\right) \square 1.13$ (d, $\left.J=12 \mathrm{~Hz}, 27 \mathrm{H}\right), 3.40$ (s, $3 \mathrm{H}) 6.70(\mathrm{~d}, J=9 \mathrm{~Hz}, 2 \mathrm{H}), 7.40(\mathrm{dd}, J=9 \mathrm{~Hz}, 2 \mathrm{~Hz}, 2 \mathrm{H}) ;{ }^{13} \mathrm{C}\left\{{ }^{1} \mathrm{H}\right\} \mathrm{NMR}\left(\mathrm{CD}_{2} \mathrm{Cl}_{2}, 126\right.$ 
$\left.\mathrm{MHz},-20^{\circ} \mathrm{C}\right) \square 31.7(\mathrm{~d}, J=2 \mathrm{~Hz}), 40.8(\mathrm{~d}, J=10 \mathrm{~Hz}), 55.2,113.0(\mathrm{~d}, J=3 \mathrm{~Hz}), 120.7$ $(\mathrm{d}, J=5 \mathrm{~Hz}), 135.6(\mathrm{~d}, J=4 \mathrm{~Hz}), 156.8 ;{ }^{31} \mathrm{P}\left\{{ }^{1} \mathrm{H}\right\} \mathrm{NMR}\left(\mathrm{C}_{6} \mathrm{D}_{6}, 122 \mathrm{MHz}\right) \square 62.3$; Anal. calcd. for $\mathrm{C}_{19} \mathrm{H}_{34}$ BrOPPd: C, 46.03; H, 6.91. Found: C, 46.14; H, 7.16.

Synthesis of $\left(\mathrm{Ph}_{5} \mathrm{FcP}^{t} \mathrm{Bu}_{2}\right) \mathrm{Pd}\left(\mathrm{C}_{6} \mathrm{H}_{4}-p\right.$-OMe $) \mathrm{Br}$ (1b). In a drybox, $p$-bromoanisole (5.00 mL, $40.0 \mathrm{mmol})$ was added to a mixture of $\mathrm{Ph}_{5} \mathrm{FcP}^{t} \mathrm{Bu}_{2}(355 \mathrm{mg}, 0.500 \mathrm{mmol})$ and $\operatorname{Pd}(\mathrm{dba})_{2}(288 \mathrm{mg}, 0.500 \mathrm{mmol})$, and the resulting mixture was stirred at room temperature for $30 \mathrm{~min}$. The reaction mixture was then added at room temperature to a flask containing vigorously stirred pentane $(60 \mathrm{~mL})$ to give a brown precipitate. The resulting suspension was filtered, and the solid was washed with ether. The solid was dissolved in THF, and the mixture was filtered. After concentration of filtrate until the solid began to precipitate, the filtrate was added at room temperature to a flask containing vigorously stirred pentane $(80 \mathrm{~mL})$ to give a brown precipitate. The brown product was isolated by filtration (324 mg, 65\%). ${ }^{1} \mathrm{H} \mathrm{NMR}\left(\mathrm{CD}_{2} \mathrm{Cl}_{2}, 400 \mathrm{MHz}\right) \square 1.03$ (d, $J=14 \mathrm{~Hz}, 18 \mathrm{H}), 3.73(\mathrm{~s}, 3 \mathrm{H}) 4.55(\mathrm{~s}, 2 \mathrm{H}), 4.77(\mathrm{~d}, J=2 \mathrm{~Hz}, 2 \mathrm{H}), 6.58(\mathrm{~d}, J=9 \mathrm{~Hz}$, $2 \mathrm{H}), 7.04-7.31(\mathrm{~m}, 27 \mathrm{H}) ;{ }^{13} \mathrm{C}\left\{{ }^{1} \mathrm{H}\right\} \mathrm{NMR}\left(\mathrm{CD}_{2} \mathrm{Cl}_{2}, 126 \mathrm{MHz}, 0{ }^{\circ} \mathrm{C}\right) \square 30.7(\mathrm{~d}, J=3 \mathrm{~Hz})$, $38.8(\mathrm{~d}, J=18 \mathrm{~Hz}), 55.5,76.3(\mathrm{~d}, J=28 \mathrm{~Hz}), 78.2(\mathrm{~d}, J=6 \mathrm{~Hz}), 79.9$ (br), 88.5, 113.7, 121.0 (br), 127.2, 128.0, 132.7, 135.1, 135.2, 157.2; ${ }^{31} \mathrm{P}\left\{{ }^{1} \mathrm{H}\right\} \mathrm{NMR}\left(\mathrm{CD}_{2} \mathrm{Cl}_{2}, 202 \mathrm{MHz}\right)$ प48.7; Anal. calcd. for $\mathrm{C}_{55} \mathrm{H}_{54} \mathrm{BrFeOPPd}$ : C, 65.79; H, 5.42. Found: C, 65.52; H, 5.23.

Synthesis of $\left[\left(\mathrm{FcP}^{t} \mathrm{Bu}_{2}\right) \mathrm{Pd}\left(\mathrm{C}_{6} \mathrm{H}_{4}-p-\mathrm{OMe}\right) \mathrm{Br}\right]_{2}(\mathbf{1 c})$. In a drybox, a mixture of $\mathrm{FcP}^{t} \mathrm{Bu}_{2}$ (694 mg, $2.10 \mathrm{mmol}), \mathrm{Pd}(\mathrm{dba})_{2}(1.15 \mathrm{~g}, 2.00 \mathrm{mmol}),{ }^{1}$ and $p$-bromoanisole $(15.0 \mathrm{~mL}$, $120 \mathrm{mmol}$ ) was stirred at room temperature for $3 \mathrm{~h}$. The reaction mixture was then added at room temperature to a flask containing vigorously stirred pentane $(120 \mathrm{~mL})$ to give an orange precipitate. The resulting suspension was filtered, and the solid was washed with ether. The solid was dissolved in $\mathrm{CH}_{2} \mathrm{Cl}_{2}$, and the mixture was filtered. Evaporation of the solvents gave the product as an orange solid $(516 \mathrm{mg}, 83 \%) .{ }^{1} \mathrm{H}$ $\operatorname{NMR}\left(\mathrm{CD}_{2} \mathrm{Cl}_{2}, 400 \mathrm{MHz}\right) \square 1.38(\mathrm{~d}, J=14 \mathrm{~Hz}, 18 \mathrm{H}), 3.73(\mathrm{~s}, 3 \mathrm{H}) 4.47(\mathrm{~s}, 5 \mathrm{H}), 4.51(\mathrm{~s}$, $2 \mathrm{H}), 4.56(\mathrm{~s}, 2 \mathrm{H}), 6.62(\mathrm{~d}, J=9 \mathrm{~Hz}, 2 \mathrm{H}), 7.18(\mathrm{dd}, J=9 \mathrm{~Hz}, 3 \mathrm{~Hz}, 2 \mathrm{H}) ;{ }^{13} \mathrm{C}\left\{{ }^{1} \mathrm{H}\right\} \mathrm{NMR}$ 
$\left(\mathrm{CD}_{2} \mathrm{Cl}_{2}, 126 \mathrm{MHz},-20{ }^{\circ} \mathrm{C}\right) \square 30.9$ (br), 38.0 (br), 55.2, 68.0, 70.7, 72.3, 74.0 (d, $J=9$ $\mathrm{Hz}), 113.1,115.5(\mathrm{~d}, J=10 \mathrm{~Hz}), 135.9,156.5 ;{ }^{31} \mathrm{P}\left\{{ }^{1} \mathrm{H}\right\} \mathrm{NMR}\left(\mathrm{CD}_{2} \mathrm{Cl}_{2}, 162 \mathrm{MHz}\right) \square 51.4$ Anal. calcd. for $\mathrm{C}_{25} \mathrm{H}_{34} \mathrm{BrFeOPPd}$ : C, 48.14; H, 5.49. Found: C, 47.88; H, 5.36.

Synthesis of $\mathbf{H N}\left[\mathbf{3 , 5}-\left(\mathbf{C F}_{3}\right)_{2} \mathbf{C}_{6} \mathbf{H}_{3}\right]_{2}$. In a drybox, $\mathrm{Pd}(\mathrm{dba})_{2}(17.3 \mathrm{mg}, 30.0 \square \mathrm{mol}){ }^{1}$ $\mathrm{Ph}_{5} \mathrm{FcP}^{t} \mathrm{Bu}_{2}(42.6 \mathrm{mg}, 60.0 \square \mathrm{mol})$, and $\mathrm{NaO}^{t} \mathrm{Bu}(346 \mathrm{mg}, 3.60 \mathrm{mmol})$ were placed in a vial. To the vial, 1,4-dioxane (6 mL), 3,5-bis(trifluoromethyl)aniline (515 $\square \mathrm{L}, 3.30$ mmol), and 3,5-bis(trifluoromethyl)bromobenzene (517 $\square \mathrm{L}, 3.00 \mathrm{mmol}$ ) were added at room temperature. After removing the vial from the drybox, the mixture was stirred at $80{ }^{\circ} \mathrm{C}$ for $21.5 \mathrm{~h}$. The reaction mixture was cooled to room temperature and diluted with $\mathrm{CH}_{2} \mathrm{Cl}_{2}$ to $20 \mathrm{~mL}$. The resulting suspension was filtered through Celite, and the Celite was washed with $\mathrm{CH}_{2} \mathrm{Cl}_{2}$. Silica gel was added to the resulting solution, and the solvent was removed under reduced pressure. The crude product was purified by column chromatography, eluting with $10 \% \mathrm{CH}_{2} \mathrm{Cl}_{2}$ in hexane to give the product as a white solid (1.26 g, 95\%). ${ }^{1} \mathrm{H}$ NMR $\left(\mathrm{CDCl}_{3}, 400 \mathrm{MHz}\right) \square 6.24$ (s, 1H), 7.50 (s, 4H), 7.53 (s, $2 \mathrm{H}) ;{ }^{13} \mathrm{C}\left\{{ }^{1} \mathrm{H}\right\} \mathrm{NMR}\left(\mathrm{CDCl}_{3}, 100 \mathrm{MHz}\right) \square 115.9\left(\mathrm{sep},{ }^{3} J_{\mathrm{CF}}=4 \mathrm{~Hz}\right), 117.8$ (q, ${ }^{3} J_{\mathrm{CF}}=3$ $\mathrm{Hz}), 123.0\left(\mathrm{q},{ }^{1} J_{\mathrm{CF}}=273 \mathrm{~Hz}\right), 133.4\left(\mathrm{q},{ }^{2} J_{\mathrm{CF}}=34 \mathrm{~Hz}\right), 142.8 ;{ }^{19} \mathrm{~F}\left\{{ }^{1} \mathrm{H}\right\} \mathrm{NMR}\left(\mathrm{CDCl}_{3}, 376\right.$ MHz) $\square-63.0$; Anal. calcd. for $\mathrm{C}_{16} \mathrm{H}_{7} \mathrm{~F}_{12} \mathrm{~N}$ : C, 43.56; H, 1.60; N, 3.17. Found: C, 43.50; $\mathrm{H}, 1.65 ; \mathrm{N}, 3.14$.

Synthesis of KN[3,5-( $\left.\left(\mathbf{C F}_{\mathbf{3}}\right)_{2} \mathbf{C}_{\mathbf{6}} \mathbf{H}_{\mathbf{3}}\right]_{\mathbf{2}}$. In a drybox, a solution of $\mathrm{KN}\left(\mathrm{SiMe}_{3}\right)_{2}(399.0 \mathrm{mg}$, $2.00 \mathrm{mmol})$ was added at room temperature to a solution of $\mathrm{HN}\left[3,5-\left(\mathrm{CF}_{3}\right)_{2} \mathrm{C}_{6} \mathrm{H}_{3}\right]_{2}(905$ $\mathrm{mg}, 2.05 \mathrm{mmol})$ in toluene $(8 \mathrm{~mL})$. The mixture was stirred at room temperature for $3 \mathrm{~h}$. The resulting yellow suspension was then filtered, and the yellow solid was washed with toluene and pentane to give the product as a yellow solid (893 mg, 93\%). ${ }^{1} \mathrm{H}$ NMR $\left(\mathrm{THF}-d_{8}, 500 \mathrm{MHz}\right) \square 6.62(\mathrm{~s}, 2 \mathrm{H}), 7.19$ (s, 2H); ${ }^{13} \mathrm{C}\left\{{ }^{1} \mathrm{H}\right\}$ NMR (THF- $\left.d_{8}, 126 \mathrm{MHz}\right)$ $\square 104.7\left(\mathrm{sep},{ }^{3} J_{\mathrm{CF}}=4 \mathrm{~Hz}\right), 117.9\left(\mathrm{q},{ }^{3} J_{\mathrm{CF}}=3 \mathrm{~Hz}\right), 125.9\left(\mathrm{q},{ }^{1} J_{\mathrm{CF}}=272 \mathrm{~Hz}\right), 132.7\left(\mathrm{q},{ }^{2} J_{\mathrm{CF}}\right.$ $=30 \mathrm{~Hz}), 159.4 ;{ }^{19} \mathrm{~F}\left\{{ }^{1} \mathrm{H}\right\}$ NMR $\left(\mathrm{THF}-d_{8}, 376 \mathrm{MHz}\right) \square-59.8$. 
Synthesis of $\left({ }^{t} \mathrm{Bu}_{3} \mathrm{P}\right) \mathrm{Pd}\left(\mathrm{C}_{6} \mathrm{H}_{4}-p-\mathrm{OMe}\right) \mathrm{N}\left[3,5-\left(\mathrm{CF}_{3}\right)_{2} \mathrm{C}_{6} \mathrm{H}_{3}\right]_{2}$ (2a). In a drybox, a mixture of $\left({ }^{t} \mathrm{Bu}_{3} \mathrm{P}\right) \mathrm{Pd}\left(\mathrm{C}_{6} \mathrm{H}_{4}-p-\mathrm{OMe}\right) \mathrm{Br}(99.1 \mathrm{mg}, 0.200 \mathrm{mmol}), \mathrm{KN}\left[3,5-\left(\mathrm{CF}_{3}\right)_{2} \mathrm{C}_{6} \mathrm{H}_{3}\right]_{2}$ $(101 \mathrm{mg}, 0.210 \mathrm{mmol})$, and ether $(5 \mathrm{~mL})$ was stirred at room temperature for $10 \mathrm{~min}$. The reaction mixture was diluted with pentane $(15 \mathrm{~mL})$, and the resulting suspension was stirred for $5 \mathrm{~min}$. The suspension was filtered through Celite, and the Celite was washed with pentane. The filtrate was evaporated to give the product as an orange solid (162 mg, 95\%). Analytically pure orange crystals of the product were obtained by recrystallization of this orange solid from a 1:5 mixture of ether and pentane at $-35^{\circ} \mathrm{C}$ (73.1 mg, 43\%). ${ }^{1} \mathrm{H}$ NMR $\left(\mathrm{C}_{6} \mathrm{D}_{6}, 400 \mathrm{MHz}\right) \square 1.09$ (d, $\left.J=13 \mathrm{~Hz}, 27 \mathrm{H}\right), 3.23$ (s, 3H), $6.41(\mathrm{~d}, J=9 \mathrm{~Hz}, 2 \mathrm{H}), 7.06(\mathrm{dd}, J=9 \mathrm{~Hz}, 1 \mathrm{~Hz}, 2 \mathrm{H}), 7.45(\mathrm{~s}, 2 \mathrm{H}), 8.09(\mathrm{~s}, 4 \mathrm{H}) ;{ }^{13} \mathrm{C}\left\{{ }^{1} \mathrm{H}\right\}$ $\operatorname{NMR}\left(\mathrm{CD}_{2} \mathrm{Cl}_{2}, 126 \mathrm{MHz}\right) \square 32.4(\mathrm{~d}, J=3 \mathrm{~Hz}), 40.5(\mathrm{~d}, J=11 \mathrm{~Hz}), 55.6,111.2$ (sep, $\left.{ }^{3} J_{\mathrm{CF}}=4 \mathrm{~Hz}\right), 113.7(\mathrm{~d}, J=1 \mathrm{~Hz}), 120.7(\mathrm{~m}), 124.5\left(\mathrm{q},{ }^{1} J_{\mathrm{CF}}=273 \mathrm{~Hz}\right), 127.6(\mathrm{~m}), 132.5$ $\left(\mathrm{q},{ }^{2} J_{\mathrm{CF}}=32 \mathrm{~Hz}\right), 133.8(\mathrm{~d}, J=3 \mathrm{~Hz}), 155.7,157.7 ;{ }^{19} \mathrm{~F}\left\{{ }^{1} \mathrm{H}\right\} \mathrm{NMR}\left(\mathrm{C}_{6} \mathrm{D}_{6}, 376 \mathrm{MHz}\right) \square-$ 62.2; ${ }^{31} \mathrm{P}\left\{{ }^{1} \mathrm{H}\right\}$ NMR $\left(\mathrm{C}_{6} \mathrm{D}_{6}, 162 \mathrm{MHz}\right) \square$ 64.9; Anal. calcd. for $\mathrm{C}_{35} \mathrm{H}_{40} \mathrm{~F}_{12} \mathrm{NOPPd}$ : , 49.10; H, 4.71; N, 1.64. Found: C, 48.97; H, 4.49; N, 1.69.

Synthesis of $\left(\mathrm{Ph}_{5} \mathrm{FcP}^{t} \mathrm{Bu}_{2}\right) \operatorname{Pd}\left(\mathrm{C}_{6} \mathrm{H}_{4}-p-\mathrm{OMe}\right) \mathbf{N}\left[3,5-\left(\mathrm{CF}_{3}\right)_{2} \mathrm{C}_{6} \mathrm{H}_{3}\right]_{2}(2 \mathrm{~b})$. In a drybox, a mixture of $\left(\mathrm{Ph}_{5} \mathrm{FcP}^{t} \mathrm{Bu}_{2}\right) \mathrm{Pd}\left(\mathrm{C}_{6} \mathrm{H}_{4}-p-\mathrm{OMe}\right) \mathrm{Br}$ (151 mg, $\left.150 \mathrm{mmol}\right), \mathrm{KN}\left[3,5-\left(\mathrm{CF}_{3}\right)_{2} \mathrm{C}_{6} \mathrm{H}_{3}\right]_{2}$ (71.9 mg, $150 \square \mathrm{mol})$, and THF (8 mL) was stirred at room temperature for $10 \mathrm{~min}$. After THF was evaporated, pentane $(15 \mathrm{~mL})$ was added to the reaction mixture. The reaction mixture was stirred at room temperature for $10 \mathrm{~min}$. The resulting suspension was filtered through Celite, and the Celite was washed with pentane and ether. The filtrate was evaporated to give the product as a deep orange-purple solid. The product was obtained as an analytically pure red powder by a second precipitation of this solid from a 1:5 mixture of ether and pentane at $-35^{\circ} \mathrm{C}(79.4 \mathrm{mg}, 39 \%) .{ }^{1} \mathrm{H}$ NMR (toluene- $d_{8}$, $400 \mathrm{MHz}) \square 0.95$ (d, $J=14 \mathrm{~Hz}, 18 \mathrm{H}), 3.19$ (s, 3H) 4.40 (s, 2H), 4.71 (d, J=1 Hz, 2H), $6.29(\mathrm{~d}, J=9 \mathrm{~Hz}, 2 \mathrm{H}), 6.85-7.00(\mathrm{~m}, 17 \mathrm{H}), 7.16(\mathrm{~d}, J=7 \mathrm{~Hz}, 10 \mathrm{H}), 7.34(\mathrm{~s}, 2 \mathrm{H}), 7.74$ $(\mathrm{s}, 4 \mathrm{H}) ;{ }^{19} \mathrm{~F}\left\{{ }^{1} \mathrm{H}\right\}$ NMR (toluene- $\left.d_{8}, 376 \mathrm{MHz}\right) \square-62.2(\mathrm{~s}) ;{ }^{31} \mathrm{P}\left\{{ }^{1} \mathrm{H}\right\}$ NMR (toluene- $d_{8}$, 
$121 \mathrm{MHz}) \square$ 54.1; Anal. calcd. for $\mathrm{C}_{71} \mathrm{H}_{60} \mathrm{~F}_{12} \mathrm{FeNOPPd}$ C, 62.50; H, 4.43; N, 1.03 . Found: C, 62.77; H, 4.60; N, 0.92 .

Synthesis of $\left(\mathrm{FcP}^{t} \mathrm{Bu}_{2}\right) \mathrm{Pd}\left(\mathrm{C}_{6} \mathrm{H}_{4}-p-\mathrm{OMe}\right) \mathrm{N}\left[3,5-\left(\mathrm{CF}_{3}\right)_{2} \mathrm{C}_{6} \mathrm{H}_{3}\right]_{2}$ (2c). In a drybox, a mixture of $\left(\mathrm{FcP}^{t} \mathrm{Bu}_{2}\right) \mathrm{Pd}\left(\mathrm{C}_{6} \mathrm{H}_{4}-p-\mathrm{OMe}\right) \mathrm{Br}(37.4 \mathrm{mg}, 30.0 \square \mathrm{mol}), \mathrm{KN}\left[3,5-\left(\mathrm{CF}_{3}\right)_{2} \mathrm{C}_{6} \mathrm{H}_{3}\right]_{2}$ (14.5 mg, $30.3 \square \mathrm{mol})$, and ether (4 mL) was stirred at room temperature for $10 \mathrm{~min}$. The reaction mixture was filtered through Celite, and the Celite was washed with pentane. The filtrate was evaporated to give the product as an orange solid (26.7 $\mathrm{mg}, 45 \%)$. Analytically pure orange crystals of the product were obtained by recrystallization of this orange solid from a 1:20 mixture of ether and pentane at $-35^{\circ} \mathrm{C}(14.7 \mathrm{mg}, 25 \%) .{ }^{1} \mathrm{H}$ $\operatorname{NMR}\left(\mathrm{C}_{6} \mathrm{D}_{6}, 400 \mathrm{MHz}\right) \square 1.15$ (d, $\left.J=14 \mathrm{~Hz}, 18 \mathrm{H}\right), 3.25$ (s, 3H), 4.16 (s, 7H), 4.41 (s, $2 \mathrm{H}), 6.53(\mathrm{~d}, J=9 \mathrm{~Hz}, 2 \mathrm{H}), 7.16(\mathrm{~d}, J=9 \mathrm{~Hz}, 2 \mathrm{H}), 7.45(\mathrm{~s}, 2 \mathrm{H}), 8.31(\mathrm{~s}, 4 \mathrm{H}) ;{ }^{13} \mathrm{C}\left\{{ }^{1} \mathrm{H}\right\}$ $\operatorname{NMR}\left(\mathrm{CD}_{2} \mathrm{Cl}_{2}, 126 \mathrm{MHz},-20^{\circ} \mathrm{C}\right) \square 30.5(\mathrm{~d}, J=4 \mathrm{~Hz}), 37.1(\mathrm{~d}, J=18 \mathrm{~Hz}), 62.9(\mathrm{~d}, J=$ $35 \mathrm{~Hz}), 70.1,71.8$ (d, $J=8 \mathrm{~Hz}), 72.4$ (d, $J=5 \mathrm{~Hz}), 110.7$ (m), 113.5, 120.5, 124.2 (q, $\left.{ }^{1} J_{\mathrm{CF}}=273 \mathrm{~Hz}\right), 126.2(\mathrm{~m}), 132.0\left(\mathrm{q},{ }^{2} J_{\mathrm{CF}}=32 \mathrm{~Hz}\right), 134.5,155.3,157.0 ;{ }^{19} \mathrm{~F}\left\{{ }^{1} \mathrm{H}\right\} \mathrm{NMR}$ $\left(\mathrm{CD}_{2} \mathrm{Cl}_{2}, 376 \mathrm{MHz}\right) \square-61.0 ;{ }^{31} \mathrm{P}\left\{{ }^{1} \mathrm{H}\right\} \mathrm{NMR}\left(\mathrm{C}_{6} \mathrm{D}_{6}, 162 \mathrm{MHz}\right) \square 50.1$; Anal. calcd. for $\mathrm{C}_{35} \mathrm{H}_{40} \mathrm{~F}_{12}$ NOPPd: C, 49.10; H, 4.71; N, 1.64. Found: C, 48.97; H, 4.49; N, 1.69.

Synthesis of $\left({ }^{t} \mathrm{Bu}_{3} \mathbf{P}\right) \mathbf{P d}\left(2\right.$-thienyl) $\mathrm{N}\left[3,5-\left(\mathrm{CF}_{3}\right)_{2} \mathrm{C}_{6} \mathrm{H}_{3}\right]_{2}$ (3). In a drybox, 2bromothiophene $(0.500 \mathrm{~mL}, 5.16 \mathrm{mmol})$ was added to a mixture of $\operatorname{Pd}\left(\mathrm{P}^{t} \mathrm{Bu}_{3}\right)_{2}(25.6 \mathrm{mg}$, $50.0 \square \mathrm{mol})$ and $\mathrm{KN}\left[3,5-\left(\mathrm{CF}_{3}\right)_{2} \mathrm{C}_{6} \mathrm{H}_{3}\right]_{2}(26.4 \mathrm{mg}, 55.0 \square \mathrm{mol})$ at room temperature. The reaction mixture was stirred at room temperature for 10 min and was poured into vigorously stirred pentane $(18 \mathrm{~mL})$ at room temperature to give a white precipitate. The resulting suspension was filtered through Celite. The solvents were evaporated from the filtrate until the volume was about $1 \mathrm{~mL}$. Pentane $(3 \mathrm{~mL})$ was added to the mixture, and the mixture was left in freezer $\left(-35^{\circ} \mathrm{C}\right)$. The red crystals were separated from the mother liquor by pipete, and the crystals were washed with cold pentane. Evaporation of residual pentane from the crystals under reduced pressure gave analytically pure product (19.8 mg, 48\%). ${ }^{1} \mathrm{H}$ NMR $\left(\mathrm{C}_{6} \mathrm{D}_{6}, 400 \mathrm{MHz}\right) \square 0.96(\mathrm{~d}, J=13 \mathrm{~Hz}, 27 \mathrm{H}), 6.40(\mathrm{~d}, J=4$ 
$\mathrm{Hz}, 1 \mathrm{H}), 6.56(\mathrm{dd}, J=5 \mathrm{~Hz}, 4 \mathrm{~Hz}, 1 \mathrm{H}), 6.83(\mathrm{~d}, J=5 \mathrm{~Hz}, 1 \mathrm{H}), 7.36(\mathrm{~s}, 2 \mathrm{H}), 8.05$ (s, $4 \mathrm{H}) ;{ }^{13} \mathrm{C}\left\{{ }^{1} \mathrm{H}\right\} \operatorname{NMR}\left(\mathrm{CD}_{2} \mathrm{Cl}_{2}, 126 \mathrm{MHz},-20{ }^{\circ} \mathrm{C}\right) \square 31.6(\mathrm{~d}, J=2 \mathrm{~Hz}), 40.5(\mathrm{~d}, J=12$ $\mathrm{Hz}), 111.2\left(\mathrm{sep},{ }^{3} J_{\mathrm{CF}}=4 \mathrm{~Hz}\right), 120.2(\mathrm{~s}), 123.1(\mathrm{~d}, J=4 \mathrm{~Hz}), 124.1\left(\mathrm{q},{ }^{1} J_{\mathrm{CF}}=273 \mathrm{~Hz}\right)$, $125.7,127.5,128.8,131.9\left(\mathrm{q},{ }^{2} J_{\mathrm{CF}}=32 \mathrm{~Hz}\right), 154.9 ;{ }^{19} \mathrm{~F}\left\{{ }^{1} \mathrm{H}\right\}$ NMR $\left(\mathrm{C}_{6} \mathrm{D}_{6}, 376 \mathrm{MHz}\right) \square-$ 62.3; ${ }^{31} \mathrm{P}\left\{{ }^{1} \mathrm{H}\right\}$ NMR $\left(\mathrm{C}_{6} \mathrm{D}_{6}, 162 \mathrm{MHz}\right) \square$ 62.6; Anal. calcd. for $\mathrm{C}_{32} \mathrm{H}_{36} \mathrm{~F}_{12} \mathrm{NPPdS}$ : C, 46.19; H, 4.36; N, 1.68. Found: C, 46.02; H, 4.20; N, 1.63.

Synthesis of (DPPF)Pd $\left(\mathrm{C}_{6} \mathrm{H}_{4}-p-\mathrm{OMe}\right) \mathrm{N}\left[3,5-\left(\mathrm{CF}_{3}\right)_{2} \mathrm{C}_{6} \mathrm{H}_{3}\right]_{2}(4)$. In a drybox, a mixture of (DPPF)Pd( $\left(\mathrm{C}_{6} \mathrm{H}_{4}-p-\mathrm{OMe}\right) \mathrm{I}^{3}(44.7 \mathrm{mg}, 50.0 \square \mathrm{mol}), \mathrm{KN}\left[3,5-\left(\mathrm{CF}_{3}\right)_{2} \mathrm{C}_{6} \mathrm{H}_{3}\right]_{2}(24.9 \mathrm{mg}$, $52.0 \square \mathrm{mol})$, THF $(2 \mathrm{~mL})$, and ether $(10 \mathrm{~mL})$ was stirred at room temperature for $10 \mathrm{~min}$. The reaction mixture was filtered through Celite, and the Celite was washed with pentane. The filtrate was evaporated to give the crude product as a dark-yellow solid. Analytically pure yellow crystals of the product were obtained by recrystallization of this dark-yellow solid from a 3:5 mixture of toluene and pentane at $-35^{\circ} \mathrm{C}(35.8 \mathrm{mg}$, 59\%). ${ }^{1} \mathrm{H}$ NMR $\left(\mathrm{CD}_{2} \mathrm{Cl}_{2}, 400 \mathrm{MHz}\right) \square 3.42(\mathrm{~s}, 3 \mathrm{H}), 4.13(\mathrm{dd}, J=4 \mathrm{~Hz}, 2 \mathrm{~Hz}, 2 \mathrm{H}), 4.24$ (brs, 2H), 4.54 (d, $J=2 \mathrm{~Hz}, 2 \mathrm{H}), 4.62(\mathrm{dd}, J=4 \mathrm{~Hz}, 2 \mathrm{~Hz}, 2 \mathrm{H}), 5.92(\mathrm{dd}, J=9 \mathrm{~Hz}, 2$ $\mathrm{Hz}, 2 \mathrm{H}), 6.26(\mathrm{t}, J=8 \mathrm{~Hz}, 2 \mathrm{H}), 6.85(\mathrm{~s}, 2 \mathrm{H}), 7.25(\mathrm{~s}, 4 \mathrm{H}), 7.29-7.69(\mathrm{~m}, 20 \mathrm{H}) ;{ }^{19} \mathrm{~F}\left\{{ }^{1} \mathrm{H}\right\}$ $\operatorname{NMR}\left(\mathrm{CD}_{2} \mathrm{Cl}_{2}, 376 \mathrm{MHz}\right) \square-62.8 ;{ }^{31} \mathrm{P}\left\{{ }^{1} \mathrm{H}\right\} \mathrm{NMR}\left(\mathrm{CD}_{2} \mathrm{Cl}_{2}, 162 \mathrm{MHz}\right) \square 17.8\left(\mathrm{~d},{ }^{2} J_{\mathrm{PP}}=\right.$ $29 \mathrm{~Hz}, 1 \mathrm{P}), 23.5\left(\mathrm{~d},{ }^{2} J_{\mathrm{PP}}=29 \mathrm{~Hz}, 1 \mathrm{P}\right)$; Anal. calcd. for $\mathrm{C}_{57} \mathrm{H}_{41} \mathrm{~F}_{12} \mathrm{FeNOP}{ }_{2} \mathrm{Pd} \cdot 1.0$ equiv of toluene: C, 59.12; H, 3.80; N, 1.08. Found: C, 59.20; H, 3.74; N, 0.92.

Synthesis of $\left(4-\mathrm{MeOC}_{6} \mathbf{H}_{4}\right) \mathbf{N}\left[3,5-\left(\mathrm{CF}_{3}\right)_{2} \mathbf{C}_{6} \mathbf{H}_{3}\right]_{2}$. In a drybox, $p$-anisidine (123 mg, $1.00 \mathrm{mmol}), \mathrm{Pd}(\mathrm{dba})_{2}(5.8 \mathrm{mg}, 10 \square \mathrm{mol}),{ }^{1} \mathrm{Ph}_{5} \mathrm{FcP}^{\prime} \mathrm{Bu}_{2}(14.2 \mathrm{mg}, 20.0 \square \mathrm{mol})$, and $\mathrm{NaO}^{t} \mathrm{Bu}(211 \mathrm{mg}, 2.20 \mathrm{mmol})$ were placed in a vial. To the vial was added toluene (2 $\mathrm{mL}$ ) and 3,5-bis(trifluoromethyl)bromobenzene (362 $\square \mathrm{L}, 2.10 \mathrm{mmol})$. After removing the vial from the drybox, the mixture was stirred at $80{ }^{\circ} \mathrm{C}$ for $19 \mathrm{~h}$. The reaction mixture was cooled to room temperature and diluted with ether to $20 \mathrm{~mL}$. The resulting suspension was filtered through Celite, and the Celite was washed with ether. Silica gel was added to the resulting solution, and the solvent was removed under reduced 
pressure. The crude product was purified by column chromatography, eluting with $1 \%$ ether in hexane to give the product as a white solid $(361 \mathrm{mg}, 66 \%) .{ }^{1} \mathrm{H} \mathrm{NMR}\left(\mathrm{CDCl}_{3}\right.$, $500 \mathrm{MHz}) \square 3.87(\mathrm{~s}, 3 \mathrm{H}), 6.97(\mathrm{dt}, J=9 \mathrm{~Hz}, 2 \mathrm{~Hz}), 7.09(\mathrm{dt}, J=9 \mathrm{~Hz}, 2 \mathrm{~Hz}), 7.42(\mathrm{~s}$, $4 \mathrm{H}), 7.49(\mathrm{~s}, 2 \mathrm{H}) ;{ }^{13} \mathrm{C}\left\{{ }^{1} \mathrm{H}\right\} \mathrm{NMR}\left(\mathrm{CDCl}_{3}, 126 \mathrm{MHz}\right) \square 55.5,116.1,116.2\left(\mathrm{sep},{ }^{3} J_{\mathrm{CF}}=4\right.$ $\mathrm{Hz}), 121.6\left(\mathrm{q},{ }^{3} J_{\mathrm{CF}}=3 \mathrm{~Hz}\right), 123.0\left(\mathrm{q},{ }^{1} J_{\mathrm{CF}}=273 \mathrm{~Hz}\right), 128.3,133.1\left(\mathrm{q},{ }^{2} J_{\mathrm{CF}}=33 \mathrm{~Hz}\right)$, 137.2, 148.2, 158.5; ${ }^{19} \mathrm{~F}\left\{{ }^{1} \mathrm{H}\right\}$ NMR $\left(\mathrm{CDCl}_{3}, 376 \mathrm{MHz}\right) \square-62.9$; Anal. calcd. for $\mathrm{C}_{23} \mathrm{H}_{13} \mathrm{~F}_{12} \mathrm{NO}: \mathrm{C}, 50.47 ; \mathrm{H}, 2.39 ; \mathrm{N}, 2.56$. Found: C, 50.47; H, 2.37; N, 2.47.

Synthesis of (2-thienyl)N[3,5-( $\left.\left(\mathbf{C F}_{3}\right)_{2} \mathbf{C}_{6} \mathbf{H}_{3}\right]_{2}$. In a drybox, $\mathrm{Pd}(\mathrm{dba})_{2}(14.4 \mathrm{mg}, 25.0$ $\square \mathrm{mol}),{ }^{1}$ bis[3,5-bis(trifluloromethyl)phenyl]amine (221 mg, $\left.0.500 \mathrm{mmol}\right), \mathrm{P}^{t} \mathrm{Bu}_{3}(5.1$ $\mathrm{mg}, 25 \square \mathrm{mol})$, and $\mathrm{NaO}^{t} \mathrm{Bu}(57.7 \mathrm{mg}, 0.600 \mathrm{mmol})$ were placed in a vial. To the vial was added toluene $(1.5 \mathrm{~mL})$ and 2-bromothiophene $(53.2 \square \mathrm{L}, 0.550 \mathrm{mmol})$. After removing the vial from the drybox, the mixture was stirred at $120{ }^{\circ} \mathrm{C}$ for $21 \mathrm{~h}$. The reaction mixture was cooled to room temperature and diluted with ether to $20 \mathrm{~mL}$. The resulting suspension was filtered through Celite, and the Celite was washed with ether. Silica gel was added to the resulting solution, and the solvent was removed under reduced pressure. The crude product was purified by column chromatography, eluting with $10 \% \mathrm{CH}_{2} \mathrm{Cl}_{2}$ in pentane, to give a white solid. This material was further purified by preparative TLC $\left(\mathrm{SiO}_{2}\right)$, eluting with $2 \% \mathrm{CH}_{2} \mathrm{Cl}_{2}$ in pentane, to give the product as a white solid (35.2 mg, 13\%). ${ }^{1} \mathrm{H} \mathrm{NMR}\left(\mathrm{CDCl}_{3}, 500 \mathrm{MHz}\right) \square 6.90(\mathrm{dd}, \mathrm{J}=4 \mathrm{~Hz}, 1 \mathrm{~Hz}$, 1H), $7.03(\mathrm{dd}, \mathrm{J}=6 \mathrm{~Hz}, 4 \mathrm{~Hz}, 1 \mathrm{H}), 7.26(\mathrm{dd}, \mathrm{J}=6 \mathrm{~Hz}, 1 \mathrm{~Hz}, 1 \mathrm{H}), 7.51(\mathrm{~s}, 4 \mathrm{H}), 7.57$ (s, $2 \mathrm{H}) ;{ }^{13} \mathrm{C}\left\{{ }^{1} \mathrm{H}\right\} \mathrm{NMR}\left(\mathrm{CDCl}_{3}, 126 \mathrm{MHz}\right) \square 117.1\left(\mathrm{sep},{ }^{3} J_{\mathrm{CF}}=3 \mathrm{~Hz}\right), 121.4\left(\mathrm{q},{ }^{3} J_{\mathrm{CF}}=4\right.$ $\mathrm{Hz}), 122.9\left(\mathrm{q},{ }^{1} J_{\mathrm{CF}}=273 \mathrm{~Hz}\right), 124.7,125.0,126.9,133.2\left(\mathrm{q},{ }^{2} J_{\mathrm{CF}}=35 \mathrm{~Hz}\right), 146.8,147.8$; ${ }^{19} \mathrm{~F}\left\{{ }^{1} \mathrm{H}\right\}$ NMR $\left(\mathrm{CDCl}_{3}, 376 \mathrm{MHz}\right) \square-62.8$; Anal. calcd. for $\mathrm{C}_{20} \mathrm{H}_{9} \mathrm{~F}_{12} \mathrm{NS}$ : C, 45.90; $\mathrm{H}$, 1.73; N, 2.68. Found: C, 45.61; H, 1.76; N, 2.39.

Kinetic analysis of reductive elimination reaction from $2 \mathrm{a}$. In a drybox, $\left({ }^{t} \mathrm{Bu} 3 \mathrm{P}\right) \mathrm{Pd}\left(\mathrm{C}_{6} \mathrm{H}_{4}-p-\mathrm{OMe}\right) \mathrm{N}\left[3,5-\left(\mathrm{CF}_{3}\right)_{2} \mathrm{C}_{6} \mathrm{H}_{3}\right]_{2}(34.2 \mathrm{mg}, 40.0 \square \mathrm{mol})$ was placed into a 1 $\mathrm{mL}$ screw-capped volumetric flask and dissolved in toluene- $d_{8}$. The solution was diluted 
to $1 \mathrm{~mL}$ to produce a solution that contained a $40.0 \mathrm{mM}$ concentration of the arylpalladium amido complex. $\mathrm{P}^{t} \mathrm{Bu}_{3}(80.9 \mathrm{mg}, 200 \square \mathrm{mol})$ was placed into another $1 \mathrm{~mL}$ screw-capped volumetric flask and dissolved in toluene. The solution was diluted to 1 $\mathrm{mL}$ to generate a solution that contained a $200 \square \mathrm{M}$ concentration of $\mathrm{P}^{t} \mathrm{Bu}_{3}$. $\mathrm{HN}[3,5-$ $\left.\left(\mathrm{CF}_{3}\right)_{2} \mathrm{C}_{6} \mathrm{H}_{3}\right]_{2}(88.2 \mathrm{mg}, 200 \square \mathrm{mol})$ was placed into a third $1 \mathrm{~mL}$ screw-capped volumetric flask and dissolved in toluene. The solution was diluted to $1 \mathrm{~mL}$ to generate a solution that contained a $200 \square \mathrm{M}$ concentration of $\mathrm{HN}\left[3,5-\left(\mathrm{CF}_{3}\right)_{2} \mathrm{C}_{6} \mathrm{H}_{3}\right]_{2}$. Six portions (100 $\square \mathrm{L}$ each, $4.00 \square \mathrm{mol}$ ) of the solution of the arylpalladium arylamido complex were transferred to six screw-capped NMR tubes containing a glass capillary filled with PhOTf in toluene- $d_{8}$ as an integration standard. To these samples were added the solutions of $\mathrm{P}^{t} \mathrm{Bu}_{3}(0,10,50,250,50$, and $50 \square \mathrm{L}$ for each sample $)$ and free amine $(0,0$, 0, 0, 50, and $50 \square \mathrm{L}$ for each sample). Toluene (300, 290, 250, 50, 250, and $250 \square \mathrm{L}$ for each sample) was then added to the NMR tubes to create a final volume of $400 \square \mathrm{L}$. The NMR tubes were removed from the drybox and shaken several times. Each sample was placed into a pre-heated $\left(75^{\circ} \mathrm{C}\right) \mathrm{NMR}$ spectrometer probe. After locking and shimming, the kinetic measurements were started immediately. The decay of the palladium amido complexe 2a was monitored at $75{ }^{\circ} \mathrm{C}$ by the intensity of the ${ }^{19} \mathrm{~F}\left\{{ }^{1} \mathrm{H}\right\}$ NMR resonance of the $\mathrm{CF}_{3}$ group vs the PhOTf standard contained in the glass capillary. Pulse delays of $6.0 \mathrm{~s}$ were used to ensure accurate integration. All measurements were performed with the multizg program of the Brucker DPX 400 spectrometer. ${ }^{19} \mathrm{~F}\left\{{ }^{1} \mathrm{H}\right\}$ NMR spectra were obtained every 64 seconds at $75{ }^{\circ} \mathrm{C}$. All data sets were fit to a first order exponential and contained data from more than 3 half-lives. The following first-order rate constants were obtained: $2.30 \pm 0.04 \times 10^{-3} \mathrm{~s}^{-1}\left(\mathrm{no}^{t} \mathrm{Bu}_{3}\right.$, no amine $) ; 2.12 \pm 0.04 \times 10^{-3} \mathrm{~s}^{-1}(1.00 \mathrm{mM}$ of $\mathrm{P}^{t} \mathrm{Bu}_{3}$, no amine); $2.14 \pm 0.03 \times 10^{-3} \mathrm{~s}^{-1}\left(5.00 \mathrm{mM}\right.$ of $\mathrm{P}^{t} \mathrm{Bu}_{3}$, no amine $) ; 2.13 \pm 0.03 \times 10^{-3} \mathrm{~s}^{-}$ ${ }^{1}\left(25.0 \mathrm{mM}\right.$ of $\mathrm{P}^{t} \mathrm{Bu}_{3}$, no amine $) ; 2.05 \pm 0.05 \times 10^{-3} \mathrm{~s}^{-1}\left(5.00 \mathrm{mM}\right.$ of $\mathrm{P}^{t} \mathrm{Bu}_{3}, 1.00 \mathrm{mM}$ of amine); $2.05 \pm 0.06 \times 10^{-3} \mathrm{~s}^{-1}\left(5.00 \mathrm{mM}\right.$ of $\mathrm{P}^{t} \mathrm{Bu}_{3}, 5.00 \mathrm{mM}$ of amine $)$. A portion of stock solution of $n$-dodecane in toluene $(100 \square \mathrm{L}, 2.55 \square \mathrm{mol}$; made from $21.7 \mathrm{mg}$ (127 $\square \mathrm{mol})$ 
of $n$-dodecane and $5 \mathrm{~mL}$ of toluene in a screw-capped volumetric flask) was added to the NMR tubes after kinetic measurement finished. The resulting solution was analyzed by GC to determine the yield of amine from reductive elimination. The yields, (all greater than $81 \%$ ) were determined with response factors measured with solutions of the amine prepared independently and $n$-dodecane.

Kinetic analysis of decomposition of $\mathbf{2 b}, \mathbf{2 c}$, and $\mathbf{3}$. In a drybox, $\mathbf{2 b}(5.5 \mathrm{mg}, 4.0$ $\square \mathrm{mol}), 2 \mathrm{c}$ (3.9 mg, $4.0 \square \mathrm{mol})$, or $3(3.3 \mathrm{mg}, 4.0 \square \mathrm{mol})$ was placed into a vial and dissolved in toluene- $d_{8}\left(100 \square \mathrm{L}\right.$ ). $\mathrm{Ph}_{5} \mathrm{FcP}^{t} \mathrm{Bu}_{2}$ (for $\mathbf{2 b}, 14.2 \mathrm{mg}, 20 \square \mathrm{mol}$ ), $\mathrm{FcP}^{t} \mathrm{Bu}_{2}$ (for 2c, $6.6 \mathrm{mg}, 20 \square \mathrm{mol}$ ), or a solution of $\mathrm{P}^{t} \mathrm{Bu}_{3}$ (for $\mathbf{3}, 200 \mathrm{mM}, 50.0 \square \mathrm{L}, 20.0 \square \mathrm{mol}$ ) in toluene was added into each vial containing corresponding palladium complex. The solution was transferred to a screw-capped NMR tube containing a glass capillary filled with PhOTf in toluene- $d_{8}$ as an integration standard. The vial was washed with toluene, and the solution was transfer to the NMR tube (100 $\square \mathrm{L}$ x 3 times). The NMR tubes were removed from the drybox and shaken several times. Each sample was placed into a preheated $\left(60{ }^{\circ} \mathrm{C}\right.$ for $\mathbf{2 b}, 75^{\circ} \mathrm{C}$ for $\mathbf{2 c}$ and $\left.\mathbf{3}\right) \mathrm{NMR}$ spectrometer probe. After locking and shimming, the kinetic measurements were started immediately. The decay of the palladium amido complexes $\mathbf{2 b}, \mathbf{2 c}$, or $\mathbf{3}$ was monitored at $60{ }^{\circ} \mathrm{C}(\mathbf{2 b})$ or $75^{\circ} \mathrm{C}(\mathbf{2 c}$ and 3) by the intensity of the ${ }^{19} \mathrm{~F}\left\{{ }^{1} \mathrm{H}\right\}$ NMR resonance of the $\mathrm{CF}_{3}$ group vs the PhOTf standard contained in the glass capillary. Pulse delays of $6.0 \mathrm{~s}$ were used to ensure accurate integration. All measurements were performed with the multizg program of the Brucker DPX 400 spectrometer. ${ }^{19} \mathrm{~F}\left\{{ }^{1} \mathrm{H}\right\}$ NMR spectra were obtained every $64 \mathrm{~s}$ at 60 ${ }^{\circ} \mathrm{C}(\mathbf{2 b})$ or $75{ }^{\circ} \mathrm{C}$ (2c and 3). All data sets were fit to a first order exponential and contained data from more than 3 half-lives. The following first-order rate constants were obtained: $\mathbf{2 b}, 1.69 \pm 0.03 \times 10^{-3} \mathrm{~s}^{-1}\left(60^{\circ} \mathrm{C}, 5.00 \mathrm{mM}\right.$ of $\left.\mathrm{Ph}_{5} \mathrm{FcP}^{t} \mathrm{Bu}_{2}\right) ; 2 \mathbf{c}, 1.01 \pm 0.02 \mathrm{x}$ $10^{-3} \mathrm{~s}^{-1}\left(75^{\circ} \mathrm{C}, 5.00 \mathrm{mM}\right.$ of $\left.\mathrm{FcP}^{t} \mathrm{Bu}_{2}\right) ; \mathbf{3}, 0.73 \pm 0.01 \times 10^{-3} \mathrm{~s}^{-1}\left(75^{\circ} \mathrm{C}, 5.00 \mathrm{mM}\right.$ of $\left.\mathrm{P}^{t} \mathrm{Bu}_{3}\right)$. A portion of stock solution of $n$-dodecane in toluene (100 $\square \mathrm{L}, 2.55 \square$ mol; made from $21.7 \mathrm{mg}(127 \square \mathrm{mol})$ of $n$-dodecane and $5 \mathrm{~mL}$ of toluene in a screw-capped volumetric 
flask) was added to the NMR tubes after kinetic measurement finished. The resulting solution was analyzed by GC to determine the yield of amine from reductive elimination. The yields ( $79 \%$ for $\mathbf{2 b}, 26 \%$ for $\mathbf{2 c}, 59 \%$ for $\mathbf{3}$ ) were determined with response factors measured with solutions of the amine prepared independently and $n$ dodecane.

Generation of $\left({ }^{t} \mathrm{Bu}_{3} \mathbf{P}\right) \mathbf{P d}\left(\mathrm{C}_{6} \mathrm{H}_{4}\right.$-p-OMe $) \mathbf{N}(\boldsymbol{p} \text {-tol })_{2}(\mathbf{2 d})$. In a drybox, $\left({ }^{t} \mathrm{Bu}{ }_{3} \mathrm{P}\right) \mathrm{Pd}\left(\mathrm{C}_{6} \mathrm{H}_{4}{ }^{-}\right.$ $p$-OMe)Br (5.0 mg, $10 \square \mathrm{mol})$ was placed into a small vial and dissolved in THF- $d_{8}$ (400 $\square \mathrm{L})$. The solution was transferred to a screw-capped NMR tube, and the NMR tube was removed from the drybox. A solution of $\mathrm{KN}(p \text {-tol })_{2}\left(150 \mathrm{mM}\right.$ in THF- $d_{8}, 100 \square \mathrm{L}, 15.0$ $\square \mathrm{mol})$ was added at $-78{ }^{\circ} \mathrm{C}$ to the solution of $\left({ }^{t} \mathrm{Bu}_{3} \mathrm{P}\right) \mathrm{Pd}\left(\mathrm{C}_{6} \mathrm{H}_{4}-p-\mathrm{OMe}\right) \mathrm{Br}$ with a gas-tight syringe sealed with Teflon tape. After shaking the mixture, the NMR tube was quickly placed into the pre-cooled NMR spectrometer probe at $-50{ }^{\circ} \mathrm{C}$. The palladium amido complex 2d was characterized by NMR spectroscopy at $-30{ }^{\circ} \mathrm{C} .{ }^{1} \mathrm{H}$ NMR (THF- $d_{8}, 400$ $\left.\mathrm{MHz},-30{ }^{\circ} \mathrm{C}\right) \square 1.46,(\mathrm{~d}, J=12 \mathrm{~Hz}, 27 \mathrm{H}), 2.16(\mathrm{~s}, 3 \mathrm{H}), 3.56(\mathrm{~s}, 3 \mathrm{H}), 6.30(\mathrm{~d}, J=8 \mathrm{~Hz}$, $2 \mathrm{H}), 6.74(\mathrm{~d}, J=8 \mathrm{~Hz}, 2 \mathrm{H}), 6.79(\mathrm{~d}, J=8 \mathrm{~Hz}, 4 \mathrm{H}), 7.10(\mathrm{~d}, J=8 \mathrm{~Hz}, 4 \mathrm{H}):{ }^{31} \mathrm{P}\left\{{ }^{1} \mathrm{H}\right\}$ NMR (THF- $\left.d_{8}, 162 \mathrm{MHz},-30{ }^{\circ} \mathrm{C}\right) \square 69.7$.

Generation of $\left({ }^{t} \mathrm{Bu}_{3} \mathbf{P}\right) \mathbf{P d}\left(\mathrm{C}_{6} \mathbf{H}_{4}-p \text {-OMe }\right)^{15} \mathbf{N P h}_{2}$. In a drybox, $\left({ }^{t} \mathrm{Bu}_{3} \mathrm{P}\right) \mathrm{Pd}\left(\mathrm{C}_{6} \mathrm{H}_{4}-p\right.$ $\mathrm{OMe}) \mathrm{Br}(5.0 \mathrm{mg}, 10 \square \mathrm{mol})$ was placed into a small vial and dissolved in THF (ca. 0.5 $\mathrm{mL}$ ). The solution was transferred to a screw-capped NMR tube, and the NMR tube was removed from the drybox. A solution of $\mathrm{K}^{15} \mathrm{NPh}_{2}(150 \mathrm{mM}$ in THF, $100 \square \mathrm{L}, 15.0 \square \mathrm{mol})$ was added at $-78{ }^{\circ} \mathrm{C}$ to the solution of $\left({ }^{t} \mathrm{Bu}_{3} \mathrm{P}\right) \mathrm{Pd}\left(\mathrm{C}_{6} \mathrm{H}_{4}-p-\mathrm{OMe}\right) \mathrm{Br}$ with a gas-tight syringe sealed with Teflon tape. After shaking the mixture, the NMR tube was quickly placed into the pre-cooled NMR spectrometer probe at $-40{ }^{\circ} \mathrm{C}$. The palladium amido complex was identified by ${ }^{31} \mathrm{P}$ NMR spectroscopy at $-40{ }^{\circ} \mathrm{C} .{ }^{31} \mathrm{P}\left\{{ }^{1} \mathrm{H}\right\}$ NMR (THF, 162 $\left.\mathrm{MHz},-40{ }^{\circ} \mathrm{C}\right) \square 64.6\left(\mathrm{~d},{ }^{2} J_{\mathrm{NP}}=40 \mathrm{~Hz}\right)$.

Kinetic analysis of reductive elimination reaction from $2 d$. In a drybox, $\left({ }^{t} \mathrm{Bu}_{3} \mathrm{P}\right) \mathrm{Pd}\left(\mathrm{C}_{6} \mathrm{H}_{4}-p-\mathrm{OMe}\right) \mathrm{Br}(19.8 \mathrm{mg}, 40.0 \square \mathrm{mol})$ was placed into a screw-capped 
volumetric flask and dissolved in THF. The solution was diluted to $1 \mathrm{~mL}$ to produce a solution that contained a $40.0 \mathrm{mM}$ concentration of the arylpalladium bromide complex. A portion of the solution of the arylpalladium bromide complex (250 $\square \mathrm{L}, 10.0 \square \mathrm{mol})$ and a glass capilary containing a THF solution of $\mathrm{P}(\mathrm{O})(\mathrm{OPh})_{3}$ as an integration standard were transferred to a screw-capped NMR tube, and the NMR tube was removed from the drybox. $\mathrm{KN}(p \text {-tol })_{2}(25.9 \mathrm{mg}, 0.110 \mathrm{mmol})$ and $\mathrm{P}^{\prime} \mathrm{Bu}_{3}(40.5 \mathrm{mg}, 0.200 \mathrm{mmol})$ were placed into another screw-capped volumetric flask and dissolved in THF. The solution was diluted to $1 \mathrm{~mL}$ to produce a solution that contained a $110 \mathrm{mM}$ concentration of the $\mathrm{KN}(p \text {-tol })_{2}$ and a $200 \mathrm{mM}$ concentration of $\mathrm{P}^{t} \mathrm{Bu}_{3}$. A portion of the THF solution of $\mathrm{KN}(p \text {-tol })_{2}$ and $\mathrm{P}^{t} \mathrm{Bu}_{3}\left(100 \square \mathrm{L}, 11.0 \square \mathrm{mol}\right.$ of $\mathrm{KN}(p \text {-tol })_{2}$ and $20.0 \square \mathrm{mol}$ of $\left.\mathrm{P}^{t} \mathrm{Bu}_{3}\right)$ was added at $-78{ }^{\circ} \mathrm{C}$ to the solution of arylpalladium bromide with a gas-tight syringe sealed with Teflon tape. After shaking the mixture, the NMR tube was quickly placed into the pre-cooled NMR spectrometer probe at $-50{ }^{\circ} \mathrm{C}$. A ${ }^{31} \mathrm{P}\left\{{ }^{1} \mathrm{H}\right\}$ NMR spectrum were obtained at $-45^{\circ} \mathrm{C}$ to ensure complete generation of the palladium amide prior to acquiring kinetic data. Several minutes after the temperature of NMR probe was elevated to $-10{ }^{\circ} \mathrm{C}$, kinetic measurements were started. The decay of the palladium amido complex $2 \mathbf{d}$ was monitored at $-10{ }^{\circ} \mathrm{C}$ by the intensity of the ${ }^{31} \mathrm{P}\left\{{ }^{1} \mathrm{H}\right\} \mathrm{NMR}$ resonance of the coordinated $\mathrm{P}^{t} \mathrm{Bu}_{3}$ vs the $\mathrm{P}(\mathrm{O})(\mathrm{OPh})_{3}$ standard contained in the glass capillary. Pulse delays of $40.0 \mathrm{~s}$ were used to ensure accurate integration. All measurements were performed with the multizg program of the Brucker DPX 400 spectrometer. ${ }^{31} \mathrm{P}\left\{{ }^{1} \mathrm{H}\right\}$ NMR spectra were obtained every 171 seconds at $-10{ }^{\circ} \mathrm{C}$. The data set was fit to a first order exponential and contained data from more than 3 halflives. The following first-order rate constant was obtained: $5.89 \pm 0.17 \times 10^{-4} \mathrm{~s}^{-1}$. The resulting solution was analyzed by GC to determine the yield of amine from reductive elimination. The yield of triarylamine $(91 \%)$ was determined with response factors measured with solutions of the amine prepared independently and $n$-dodecane. 


\section{References for Synthetic Procedures}

(1) Ukai, T.; Kawazura, H.; Ishii, Y. J. Organomet. Chem. 1974, 65, 253-266.

(2) Kruis, D.; Markies, B. A.; Canty, A. J.; Boersma, J.; van Koten, G. J. Organomet. Chem. 1997, 532, 235-242.

(3) Driver, M. S.; Hartwig, J. F. J. Am. Chem. Soc. 1997, 119, 8232-8245. 


\section{Details of X-ray analyses.}

Table 1. Crystal data and structure refinement for $\mathbf{2 a}, \mathbf{2 b}, \mathbf{2 c}, \mathbf{3}$, and 4 .

\begin{tabular}{|c|c|c|c|}
\hline & $2 a$ & $2 \mathbf{b}$ & 2c \\
\hline Empirical formula & $\mathrm{C}_{41} \mathrm{H}_{40} \mathrm{~F}_{12} \mathrm{Fe}$ N O P Pd & $\mathrm{C}_{71} \mathrm{H}_{60} \mathrm{~F}_{12} \mathrm{Fe}$ N O P Pd & $\mathrm{C}_{35} \mathrm{H}_{40} \mathrm{~F}_{12} \mathrm{~N}$ O P Pd \\
\hline Formula weight & 983.96 & 1364.42 & 856.05 \\
\hline Temperature & $173(2) \mathrm{K}$ & $173(2) \mathrm{K}$ & $123(2) \mathrm{K}$ \\
\hline Wavelength & $0.71073 \AA$ & $0.71073 \AA$ & $0.71073 \AA$ \\
\hline Crystal system & Monoclinic & Monoclinic & Monoclinic \\
\hline Space group & $\mathrm{P} 2(1) / \mathrm{c}$ & $\mathrm{P} 2(1) / \mathrm{c}$ & $\mathrm{P} 2(1) / \mathrm{c}$ \\
\hline Unit cell dimensions & $\mathrm{a}=10.251(2) \AA$ & $\mathrm{a}=14.979(3) \AA$ & $\mathrm{a}=19.969(4) \AA$ \\
\hline & $\mathrm{b}=19.822(4) \AA$ & $\mathrm{b}=17.638(4) \AA$ & $\mathrm{b}=18.076(4) \AA$ \\
\hline & $\mathrm{c}=20.200(4) \AA$ & $\mathrm{c}=24.486(5) \AA$ & $\mathrm{c}=21.147(4) \AA$ \\
\hline & $\square=90^{\circ}$ & $\square=90^{\circ}$ & $\square=90^{\circ}$ \\
\hline & $\square=94.75(3)^{\circ}$ & $\square=103.70(3)^{\circ}$ & $\square=105.17(3)^{\circ}$ \\
\hline & $\square=90^{\circ}$ & $\square=90^{\circ}$ & $\square=90^{\circ}$ \\
\hline Volume & $4090.5(14) \AA^{3}$ & $6285(2) \AA^{3}$ & $7368(3) \AA^{3}$ \\
\hline $\mathrm{Z}$ & 4 & 4 & 8 \\
\hline Density (calculated) & $1.598 \mathrm{~g} / \mathrm{cm}^{3}$ & $1.442 \mathrm{~g} / \mathrm{cm}^{3}$ & $1.544 \mathrm{~g} / \mathrm{cm}^{3}$ \\
\hline Absorption coefficient & $9.22 \mathrm{~cm}^{-1}$ & $6.23 \mathrm{~cm}^{-1}$ & $6.37 \mathrm{~cm}^{-1}$ \\
\hline $\mathrm{F}(000)$ & 1984 & 2784 & 3472 \\
\hline Crystal size & $0.30 \times 0.30 \times 0.25 \mathrm{~mm}^{3}$ & $0.20 \times 0.20 \times 0.10 \mathrm{~mm}^{3}$ & $0.30 \times 0.20 \times 0.20 \mathrm{~mm}^{3}$ \\
\hline Theta range for data collection & 2.24 to $27.89^{\circ}$ & 2.26 to $28.26^{\circ}$ & 2.29 to $28.31^{\circ}$ \\
\hline Index ranges & $\begin{array}{l}-13<=\mathrm{h}<=13 \\
-26<=\mathrm{k}<=23 \\
-26<=\mathrm{l}<=26\end{array}$ & $\begin{array}{l}-19<=\mathrm{h}<=19 \\
23<=\mathrm{k}<=23 \\
32<=\mathrm{l}<=32\end{array}$ & $\begin{array}{l}-26<=\mathrm{h}<=26 \\
-18<=\mathrm{k}<=24 \\
-28<=1<=28\end{array}$ \\
\hline Reflections collected & 17030 & 27821 & 26976 \\
\hline Independent reflections & $9738[\mathrm{R}(\mathrm{int})=0.0424]$ & $15448[\mathrm{R}($ int $)=0.0710]$ & $17759[\mathrm{R}($ int $)=0.0470]$ \\
\hline Completeness to theta $=27.89^{\circ}$ & $99.5 \%$ & $99.3 \%$ & $96.9 \%$ \\
\hline Absorption correction & None & None & None \\
\hline Max. and min. transmission & 0.8023 and 0.7695 & 0.9404 and 0.8856 & 0.8832 and 0.8319 \\
\hline Refinement method & $\begin{array}{l}\text { Full-matrix } \\
\text { least-squares on } \mathrm{F}^{2}\end{array}$ & $\begin{array}{l}\text { Full-matrix } \\
\text { least-squares on } \mathrm{F}^{2}\end{array}$ & $\begin{array}{l}\text { Full-matrix } \\
\text { least-squares on } \mathrm{F}^{2}\end{array}$ \\
\hline Data / restraints / parameters & $9738 / 0 / 523$ & $15448 / 0 / 849$ & $17759 / 0 / 947$ \\
\hline Goodness-of-fit on $\mathrm{F}^{2}$ & 1.029 & 1.004 & 1.002 \\
\hline Final $R$ indices $[\mathrm{I}>2 \operatorname{sigma}(\mathrm{I})]$ & $\begin{array}{l}\mathrm{R} 1=0.0434 \\
\mathrm{wR} 2=0.0962\end{array}$ & $\begin{array}{l}\mathrm{R} 1=0.0536 \\
\mathrm{wR} 2=0.1004\end{array}$ & $\begin{array}{l}\mathrm{R} 1=0.0546 \\
\mathrm{wR} 2=0.1127\end{array}$ \\
\hline $\mathrm{R}$ indices (all data) & $\begin{array}{l}\mathrm{R} 1=0.0883 \\
\mathrm{wR} 2=0.1094\end{array}$ & $\begin{array}{l}\mathrm{R} 1=0.1332 \\
\mathrm{wR} 2=0.1213\end{array}$ & $\begin{array}{l}\mathrm{R} 1=0.1292 \\
\mathrm{wR} 2=0.1356\end{array}$ \\
\hline Largest diff. peak and hole & 0.678 and -0.591 e. $\AA^{-3}$ & 0.619 and -0.660 e..$\AA^{-3}$ & 1.039 and -0.901 e. $\AA^{-3}$ \\
\hline
\end{tabular}




\begin{tabular}{|c|c|c|}
\hline & 3 & 4 \\
\hline Empirical formula & $\mathrm{C}_{32} \mathrm{H}_{36} \mathrm{~F}_{12}$ N P Pd S & $\mathrm{C}_{67.5} \mathrm{H}_{53} \mathrm{~F}_{12} \mathrm{Fe} \mathrm{NO} \mathrm{P}_{2} \mathrm{Pd}$ \\
\hline Formula weight & 832.05 & 1346.30 \\
\hline Temperature & $173(2) \mathrm{K}$ & $173(2) \mathrm{K}$ \\
\hline Wavelength & $0.71073 \AA$ & $0.71073 \AA$ \\
\hline Crystal system & Triclinic & Triclinic \\
\hline Space group & $\mathrm{P}-1$ & $\mathrm{P}-1$ \\
\hline \multirow[t]{6}{*}{ Unit cell dimensions } & $\mathrm{a}=12.301(3) \AA$ & $\mathrm{a}=13.525(3) \AA$ \\
\hline & $\mathrm{b}=12.824(3) \AA$ & $\mathrm{b}=15.326(3) \AA$ \\
\hline & $\mathrm{c}=14.038(3) \AA$ & $\mathrm{c}=15.580(3) \AA$ \\
\hline & $\square=63.30(3)^{\circ}$ & $\square=73.57(3)^{\circ}$ \\
\hline & $\square=67.09(3)^{\circ}$ & $\square=71.97(3)^{\circ}$ \\
\hline & $\square=71.43(3)^{\circ}$ & $\square=81.58(3)^{\circ}$ \\
\hline Volume & $1794.3(6) \AA^{3}$ & $2939.2(10) \AA^{3}$ \\
\hline $\mathrm{Z}$ & 2 & 2 \\
\hline Density (calculated) & $1.540 \mathrm{~g} / \mathrm{cm}^{3}$ & $1.521 \mathrm{~g} / \mathrm{cm}^{3}$ \\
\hline Absorption coefficient & $7.06 \mathrm{~cm}^{-1}$ & $6.91 \mathrm{~cm}^{-1}$ \\
\hline $\mathrm{F}(000)$ & 840 & 1366 \\
\hline Crystal size & $0.25 \times 0.25 \times 0.20 \mathrm{~mm}^{3}$ & $0.25 \times 0.25 \times 0.20 \mathrm{~mm}^{3}$ \\
\hline Theta range for data collection & 2.33 to $27.98^{\circ}$ & 2.41 to $26.00^{\circ}$. \\
\hline Index ranges & $-16<=h<=16$ & $-16<=h<=16$ \\
\hline & $-16<=\mathrm{k}<=1$ & $18<=\mathrm{k}<=18$ \\
\hline & $-18<=1<=18$ & $19<=1<=19$ \\
\hline Reflections collected & 14550 & 20270 \\
\hline Independent reflections & $8560[\mathrm{R}($ int $)=0.0378]$ & $11466[\mathrm{R}(\mathrm{int})=0.0396]$ \\
\hline Completeness to theta $=27.89^{\circ}$ & $98.9 \%$ & $99.4 \%$ \\
\hline Absorption correction & None & None \\
\hline Max. and min. transmission & 0.8718 and 0.8433 & 0.8742 and 0.8463 \\
\hline Refinement method & $\begin{array}{l}\text { Full-matrix } \\
\text { least-squares on } \mathrm{F}^{2}\end{array}$ & $\begin{array}{l}\text { Full-matrix } \\
\text { least-squares on } \mathrm{F}^{2}\end{array}$ \\
\hline Data / restraints / parameters & $8560 / 0 / 488$ & $11466 / 0 / 782$ \\
\hline Goodness-of-fit on $\mathrm{F}^{2}$ & 1.082 & 1.047 \\
\hline Final $R$ indices $[\mathrm{I}>2 \operatorname{sigma}(\mathrm{I})]$ & $\begin{array}{l}\mathrm{R} 1=0.0454 \\
\mathrm{wR} 2=0.1009\end{array}$ & $\begin{array}{l}\mathrm{R} 1=0.0485 \\
\mathrm{wR} 2=0.1253\end{array}$ \\
\hline $\mathrm{R}$ indices (all data) & $\begin{array}{l}\mathrm{R} 1=0.0710 \\
\mathrm{wR} 2=0.1094\end{array}$ & $\begin{array}{l}\mathrm{R} 1=0.0781 \\
\mathrm{wR} 2=0.1388\end{array}$ \\
\hline Largest diff. peak and hole & 0.628 and -0.925 e. $\AA^{-3}$ & 1.023 and $-0.671 \mathrm{e} . \AA^{-3}$ \\
\hline
\end{tabular}


Experimental details for the crystal structure determination of $\mathbf{2 a}$.

Data Collection: A red-orange block crystal of $\mathrm{C}_{35} \mathrm{H}_{40} \mathrm{~F}_{12} \mathrm{NOPPd}$ having approximate dimensions of $0.30 \times 0.20 \times 0.20 \mathrm{~mm}$ was mounted with epoxy cement on the tip of a fine glass fiber. All measurements were made on a Nonius KappaCCD diffractometer with graphite monochromated Mo-K $\square$ radiation. Cell constants and an orientation matrix for data collection corresponded to a primitive monoclinic cell with dimensions:

$$
\begin{array}{lll}
\mathrm{a}=19.969(4) \AA & \square=90 \mathrm{o} \\
\mathrm{b}=18.076(4) \AA & \square=105.17(3) \mathrm{O} \\
\mathrm{c}=21.147(4) \AA & \square=90 \mathrm{O} \\
\mathrm{V}=7368(3) \AA^{3} &
\end{array}
$$

For $\mathrm{Z}=8$ and F.W. $=856.05$, the calculated density is $1.544 \mathrm{~g} / \mathrm{cm}^{3}$. Based on a statistical analysis of intensity distribution, and the successful solution and refinement of the structure, the space group was determined to be: $P 2{ }_{1} / c(\# 14)$

The data were collected at a temperature of $123(2) \mathrm{K}$ to a maximum $2 \square$ value of $56.62^{\circ}$. Four omega scans consisting of 47, 37, 43, and 24 data frames, respectively, were collected with a frame width of $1.6^{\circ}$ and a detector-to-crystal distance, Dx, of $35.0 \mathrm{~mm}$. Each frame was exposed twice (for the purpose of de-zingering) for a total of 32 seconds. The data frames were processed and scaled using the DENZO software package. ${ }^{1}$

A total of 26976 reflections were collected of which 17759 were unique and observed $\left(\mathrm{R}_{\mathrm{int}}=0.0470\right)$. The linear absorption coefficient, $\square$, for Mo-K $\square$ radiation is $6.37 \mathrm{~cm}^{-1}$, and no absorption correction was applied. The data were corrected for Lorentz and polarization effects.

The structure was solved by direct methods and expanded using Fourier techniques. ${ }^{2}$ The non-hydrogen atoms were refined anisotropically, and hydrogen atoms were treated as idealized contributions. The final cycle of full-matrix least-squares refinement ${ }^{3}$ on $\mathrm{F}$ was based on 17759 observed reflections (I > 2.00 $\square(\mathrm{I})$ ) and 947 variable parameters and converged with unweighted and weighted agreement factors of:

$$
\begin{gathered}
\mathrm{R}=\square\|\mathrm{Fol}-|\mathrm{Fc} \| / \square| \mathrm{Fo} \mid=0.0546 \\
\mathrm{R}_{\mathrm{W}}=\left\{\square\left[\mathrm{w}\left(\mathrm{F}_{\mathrm{o}}{ }^{2}-\mathrm{F}_{\mathrm{c}}{ }^{2}\right)^{2}\right] / \square\left[\mathrm{w}\left(\mathrm{F}_{\mathrm{o}}{ }^{2}\right)^{2}\right]\right\}^{1 / 2}=0.1128
\end{gathered}
$$

The maximum and minimum peaks on the final difference Fourier map corresponded to 1.039 and $-0.901 \mathrm{e}^{-} / \AA^{3}$, respectively. 
Figure S1. ORTEP drawings of two independent molecules of 2a.
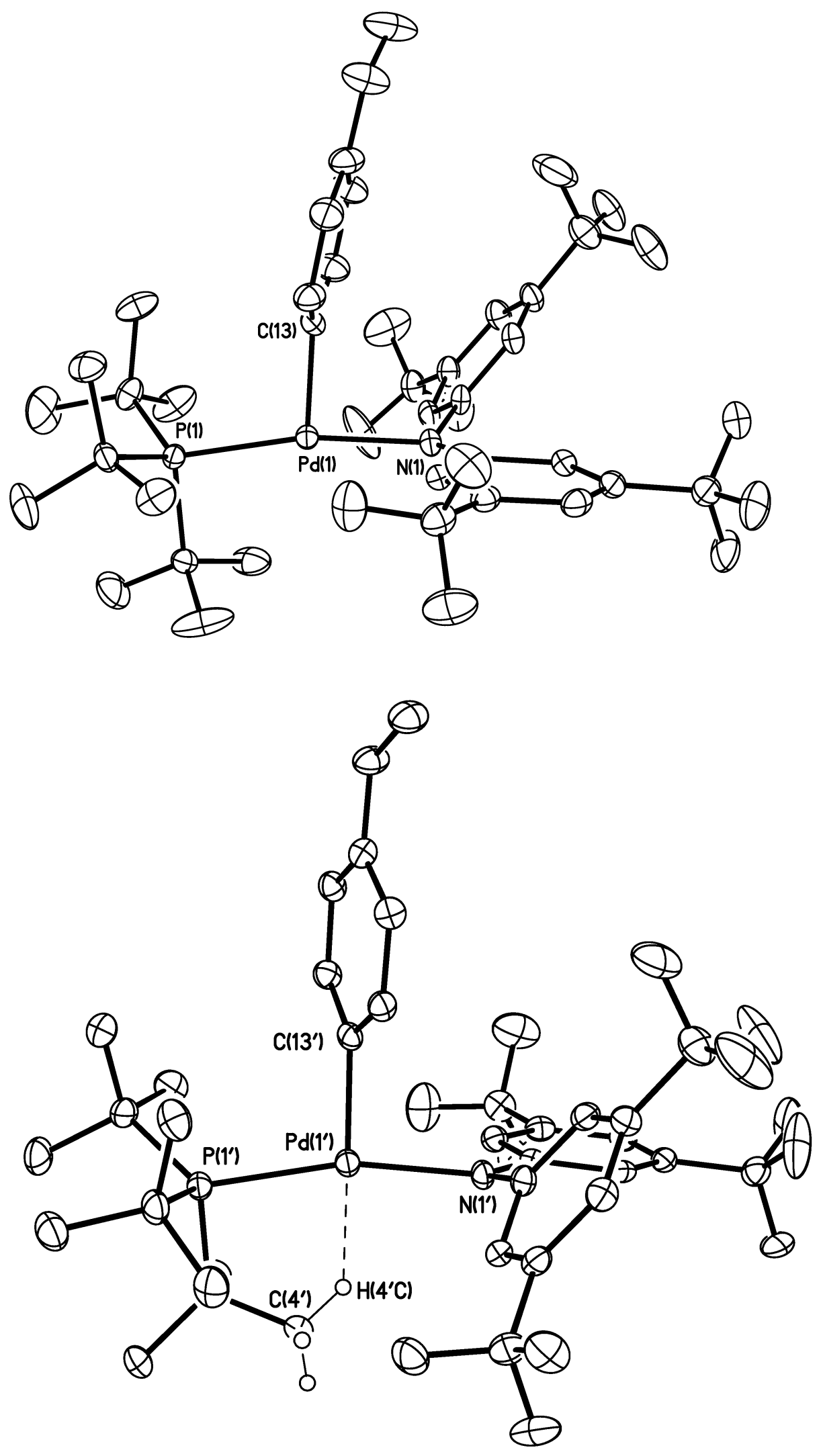
Figure S2. Palladium square plane and closest hydrogen atoms in first independent molecule of $\mathbf{2 a}$.

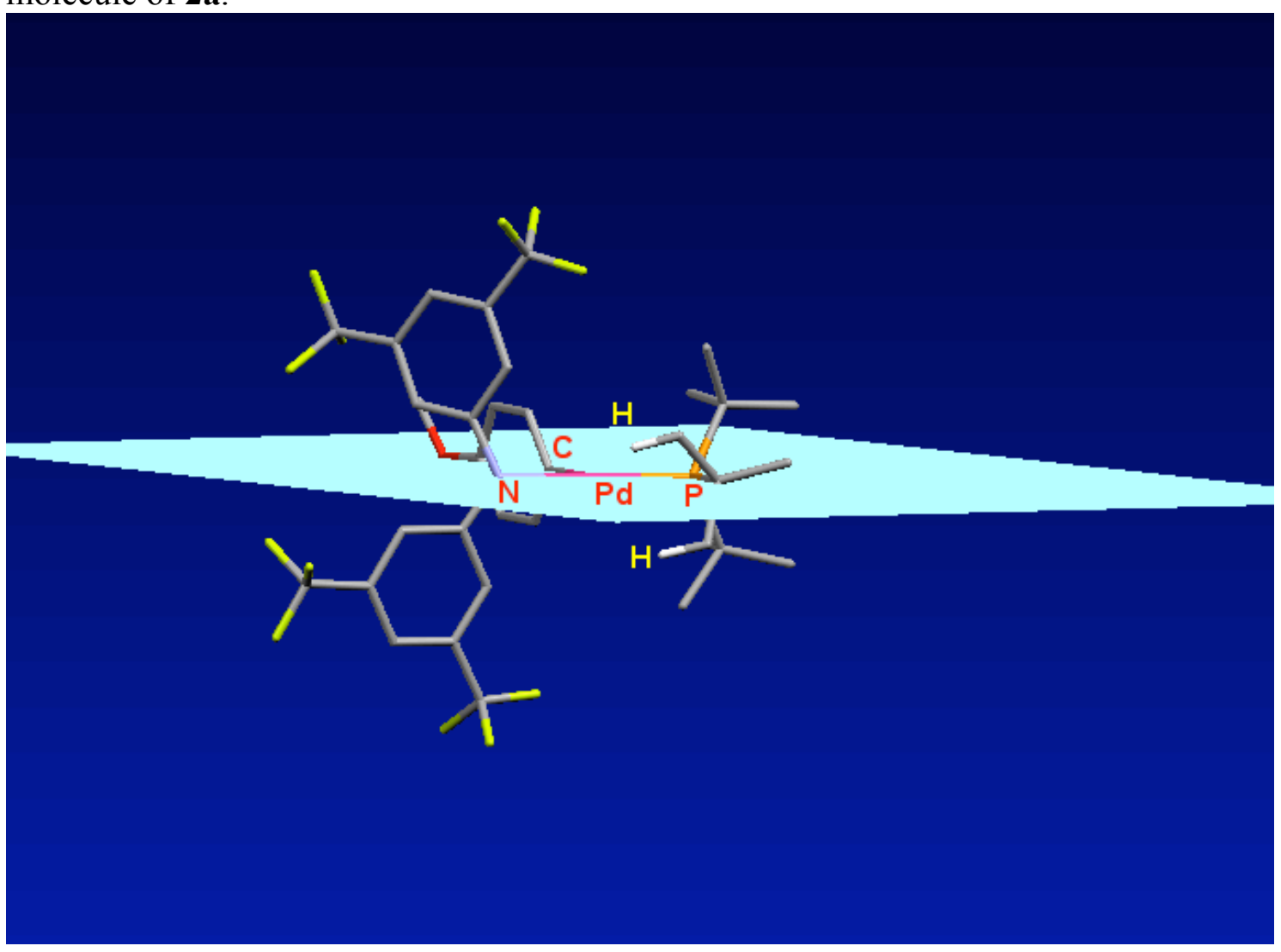


Experimental details for the crystal structure determination of $\mathbf{2 b}$.

A red plate crystal of $\mathrm{C}_{71} \mathrm{H}_{60} \mathrm{~F}_{12} \mathrm{FeNOPPd}$ having approximate dimensions of $0.20 \mathrm{x}$ $0.20 \times 0.10 \mathrm{~mm}$ was mounted with epoxy cement on the tip of a fine glass fiber. All measurements were made on a Nonius KappaCCD diffractometer with graphite monochromated Mo-K $\square$ radiation. Cell constants and an orientation matrix for data collection corresponded to a primitive monoclinic cell with dimensions:

$$
\begin{array}{lll}
\mathrm{a}=14.979(3) \AA & \square=90^{\circ} \\
\mathrm{b}=17.638(4) \AA & \square=103.70(3)^{\circ} \\
\mathrm{c}=24.486(5) \AA & \square=90^{\circ} \\
\mathrm{V}=6285(2) \AA^{3} & &
\end{array}
$$

For $\mathrm{Z}=4$ and F.W. $=1364.42$, the calculated density is $1.442 \mathrm{~g} / \mathrm{cm}^{3}$. Based on a statistical analysis of intensity distribution, and the successful solution and refinement of the structure, the space group was determined to be: $P 2_{1} / c$ (\#14)

The data were collected at a temperature of $173(2) \mathrm{K}$ to a maximum $2 \square$ value of $56.52^{\circ}$. Five omega scans consisting of 49,63, 57, 37, and 32 data frames, respectively, were collected with a frame width of $1.2^{\circ}$ and a detector-to-crystal distance, Dx, of $35.0 \mathrm{~mm}$. Each frame was exposed twice (for the purpose of de-zingering) for a total of 180 seconds. The data frames were processed and scaled using the DENZO software package. ${ }^{1}$

A total of 27821 reflections were collected of which 15448 were unique and observed $\left(\mathrm{R}_{\mathrm{int}}=0.0710\right)$. The linear absorption coefficient, $\square$, for Mo-K $\square$ radiation is $6.23 \mathrm{~cm}^{-1}$, and no absorption correction was applied. The data were corrected for Lorentz and polarization effects.

The structure was solved by direct methods and expanded using Fourier techniques. ${ }^{2}$ The non-hydrogen atoms were refined anisotropically and hydrogen atoms were treated as idealized contributions. The final cycle of full-matrix least-squares refinement ${ }^{3}$ on $\mathrm{F}$ was based on 15448 observed reflections (I > 2.00ロ(I)) and 849 variable parameters and converged with unweighted and weighted agreement factors of:

$$
\begin{gathered}
\mathrm{R}=\square\|\mathrm{Fol}-|\mathrm{Fc} \| / \square| \mathrm{Fol}=0.0536 \\
\mathrm{R}_{\mathrm{W}}=\left\{\square\left[\mathrm{w}\left(\mathrm{F}_{\mathrm{o}}{ }^{2}-\mathrm{F}_{\mathrm{c}}{ }^{2}\right)^{2}\right] / \square\left[\mathrm{w}\left(\mathrm{F}_{\mathrm{o}}{ }^{2}\right)^{2}\right]\right\}^{1 / 2}=0.1004
\end{gathered}
$$

The maximum and minimum peaks on the final difference Fourier map corresponded to 0.619 and $-0.660 \mathrm{e}^{-} / \AA^{3}$, respectively. 
Figure S3. ORTEP drawing of molecule $\mathbf{2 b}$.

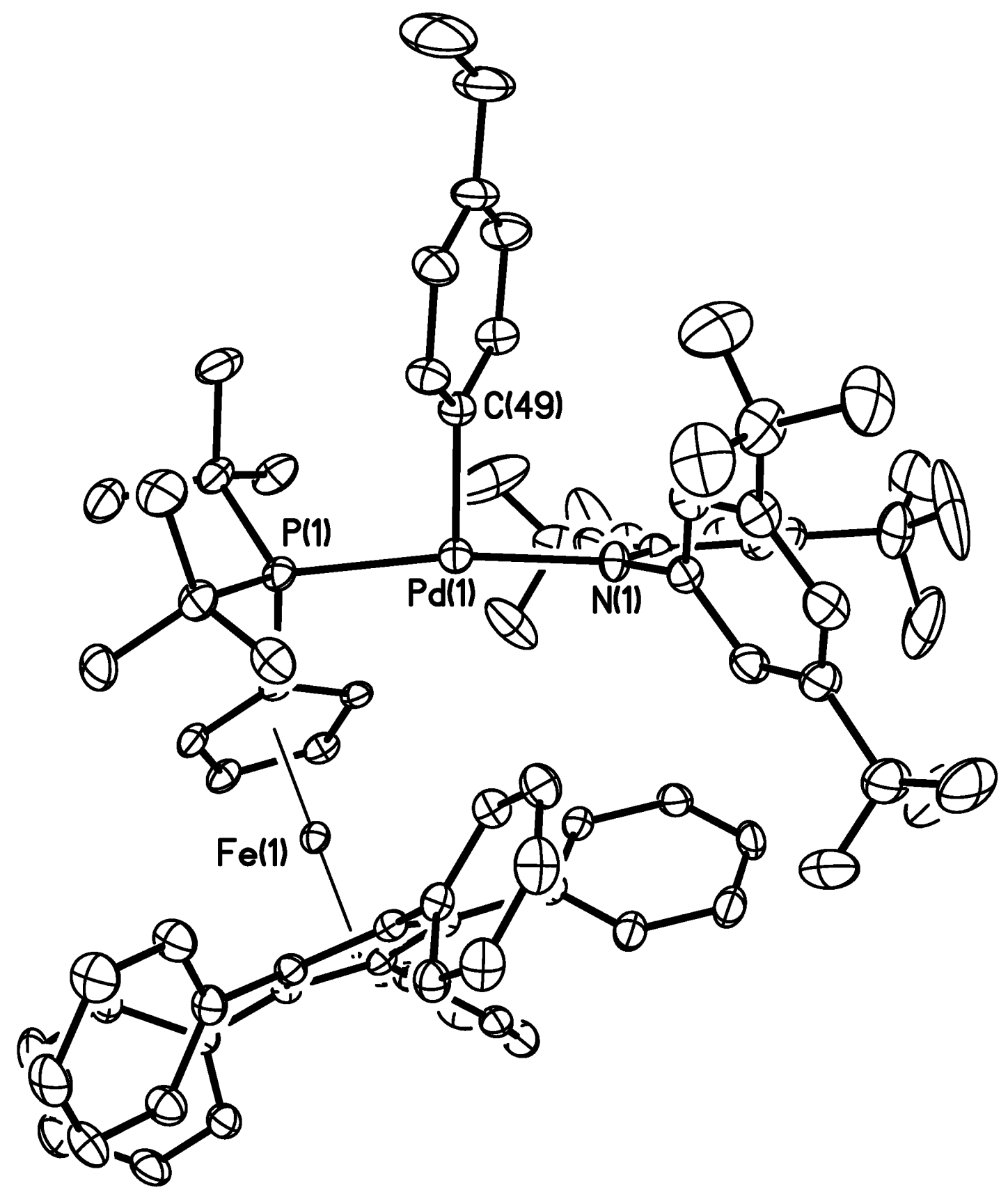


Figure S4. Palladium square plane and closest hydrogen atoms in $\mathbf{2 b}$.

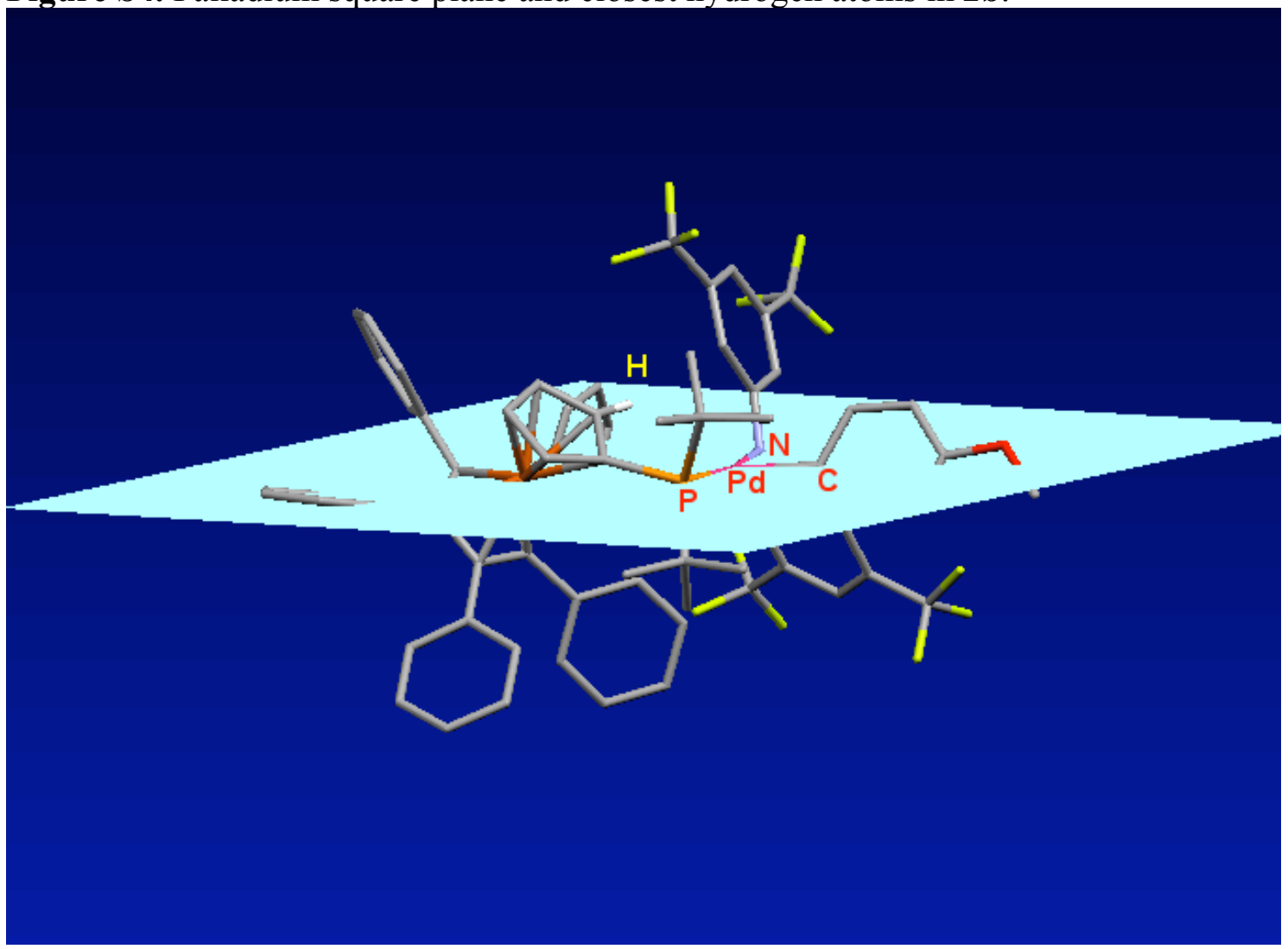


Experimental details for the crystal structure determination of $\mathbf{2 c}$.

An orange block crystal of $\mathrm{C}_{41} \mathrm{H}_{40} \mathrm{~F}_{12} \mathrm{FeNOPPd}$ having approximate dimensions of $0.30 \times 0.30 \times 0.25 \mathrm{~mm}$ was mounted with epoxy cement on the tip of a fine glass fiber. All measurements were made on a Nonius KappaCCD diffractometer with graphite monochromated Mo-K $\square$ radiation. Cell constants and an orientation matrix for data collection corresponded to a primitive monoclinic cell with dimensions:

$$
\begin{array}{lll}
\mathrm{a}=10.251(2) \AA & \square=90^{\circ} \\
\mathrm{b}=19.822(4) \AA & \square=94.75(3)^{\circ} \\
\mathrm{c}=20.200(4) \AA & \square=90^{\circ} \\
\mathrm{V}=4090.5(14) \AA^{3} & &
\end{array}
$$

For $\mathrm{Z}=4$ and F.W. $=983.96$, the calculated density is $1.598 \mathrm{~g} / \mathrm{cm}^{3}$. Based on a statistical analysis of intensity distribution, and the successful solution and refinement of the structure, the space group was determined to be: $P 2_{1} / c$ (\#14)

The data were collected at a temperature of $173(2) \mathrm{K}$ to a maximum $2 \square$ value of $55.78^{\circ}$. Five omega scans consisting of 47, 47, 37, 37, and 12 data frames, respectively, were collected with a frame width of $1.6^{\circ}$ and a detector-to-crystal distance, Dx, of $35.0 \mathrm{~mm}$. Each frame was exposed twice (for the purpose of de-zingering) for a total of 16 seconds. The data frames were processed and scaled using the DENZO software package. ${ }^{1}$

A total of 17030 reflections were collected of which 9738 were unique and observed $\left(\mathrm{R}_{\text {int }}=0.0424\right)$. The linear absorption coefficient, $\square$, for Mo-K $\square$ radiation is $9.22 \mathrm{~cm}^{-1}$, and no absorption correction was applied. The data were corrected for Lorentz and polarization effects.

The structure was solved by direct methods and expanded using Fourier techniques. ${ }^{2}$ The non-hydrogen atoms were refined anisotropically, and hydrogen atoms were treated as idealized contributions. The final cycle of full-matrix least-squares refinement ${ }^{3}$ on $\mathrm{F}$ was based on 9738 observed reflections ( $\mathrm{I}>2.00 \square(\mathrm{I})$ ) and 523 variable parameters and converged with unweighted and weighted agreement factors of:

$$
\begin{gathered}
\mathrm{R}=\square\|\mathrm{Fol}-|\mathrm{Fc} \| / \square| \mathrm{Fo} \mid=0.0434 \\
\mathrm{R}_{\mathrm{W}}=\left\{\square\left[\mathrm{w}\left(\mathrm{F}_{\mathrm{o}}{ }^{2}-\mathrm{F}_{\mathrm{c}}{ }^{2}\right)^{2}\right] / \square\left[\mathrm{w}\left(\mathrm{F}_{\mathrm{o}}{ }^{2}\right)^{2}\right]\right\}^{1 / 2}=0.0962
\end{gathered}
$$

The maximum and minimum peaks on the final difference Fourier map corresponded to 0.678 and $-0.591 \mathrm{e}^{-} / \AA^{3}$, respectively. 
Figure S5. ORTEP drawing of molecule 2c.

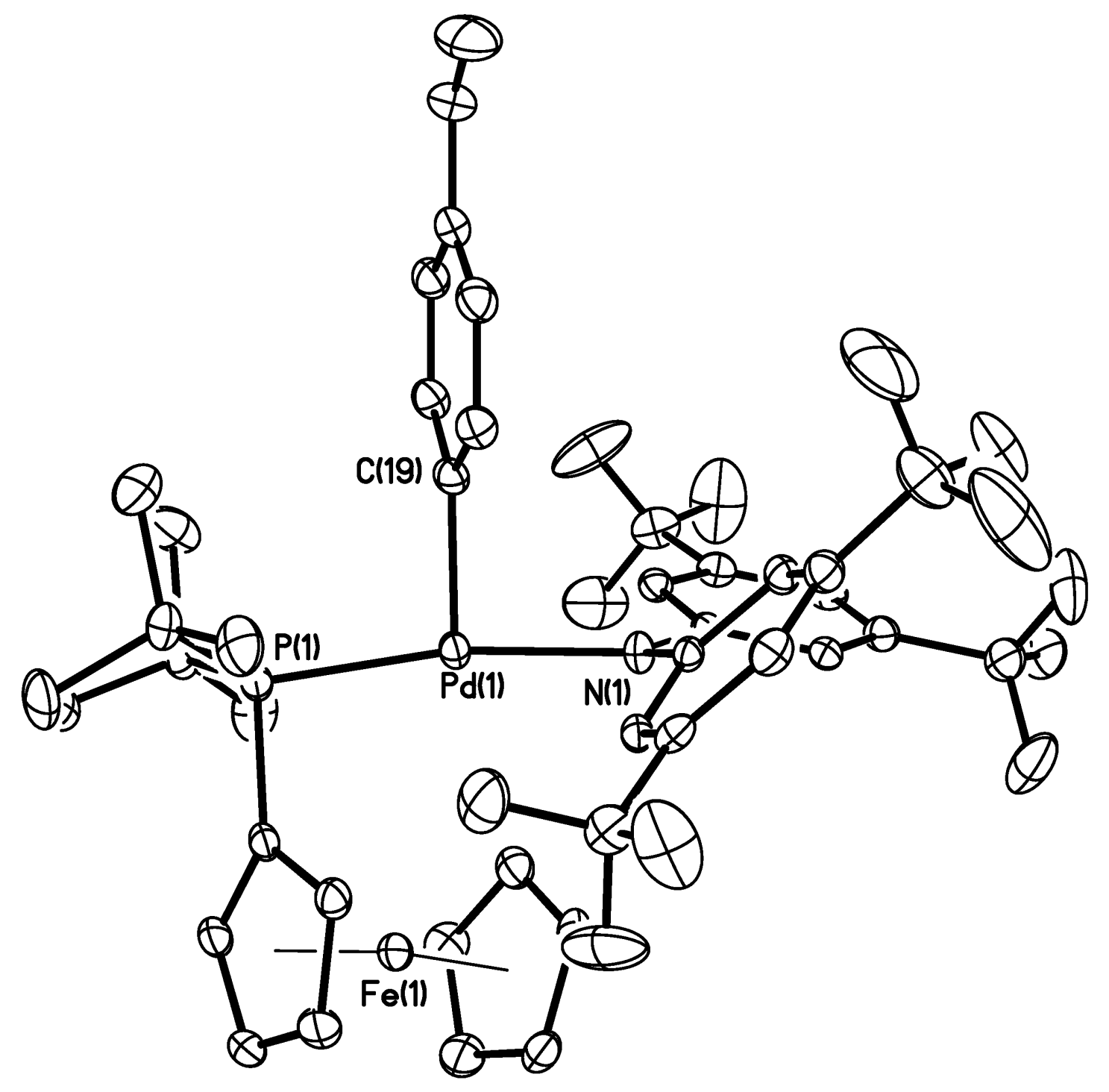


S23

Figure S6. Palladium square plane and closest hydrogen atoms in $\mathbf{2 c .}$

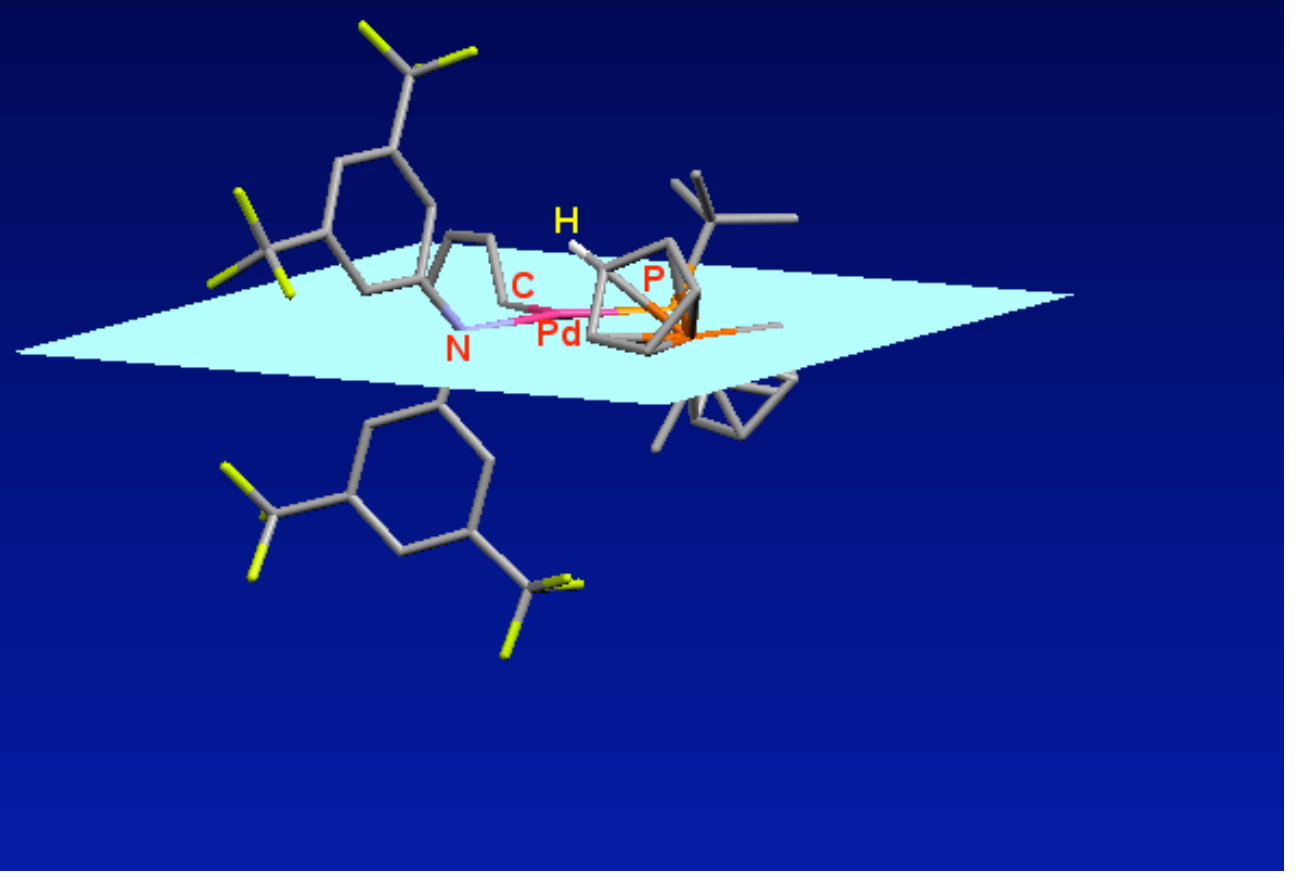


Experimental details for the crystal structure determination of 3.

A red block crystal of $\mathrm{C}_{32} \mathrm{H}_{36} \mathrm{~F}_{12} \mathrm{NPPdS}$ having approximate dimensions of $0.25 \mathrm{x}$ $0.25 \times 0.20 \mathrm{~mm}^{3}$ was mounted with epoxy cement on the tip of a fine glass fiber. All measurements were made on a Nonius KappaCCD diffractometer with graphite monochromated Mo-K $\square$ radiation. Cell constants and an orientation matrix for data collection corresponded to a triclinic cell with dimensions:

$$
\begin{array}{llll}
\mathrm{a}= & 12.301(3) \AA & \square=63.30(3)^{\mathrm{O}} \\
\mathrm{b}=12.824(3) & \AA & \square=67.09(3)^{\mathrm{O}} \\
\mathrm{c}= & 14.038(3) \AA & \square= & 71.43(3)^{\circ} \\
\mathrm{V}=1794.3(6) \AA^{3} & &
\end{array}
$$

For $\mathrm{Z}=2$ and F.W. $=832.05$, the calculated density is $1.540 \mathrm{~g} / \mathrm{cm}^{3}$. Based on a statistical analysis of intensity distribution, and the successful solution and refinement of the structure, the space group was determined to be $P-1$ (\#2). The data were collected at a temperature of $173(2) \mathrm{K}$ to a maximum $2 \square$ value of $55.96^{\circ}$. Seven omega scans consisting of 37, 37, 34, 29, 24, 27, and 7 data frames, respectively, were collected with a frame width of $2.0^{\circ}$ and a detector-to-crystal distance, Dx, of $35.0 \mathrm{~mm}$. Each frame was exposed twice (for the purpose of de-zingering) for a total of 20 seconds. The data frames were processed and scaled using the DENZO software package. ${ }^{1}$

A total of 14550 reflections were collected of which 8560 were unique and observed $\left(\mathrm{R}_{\mathrm{int}}=0.0378\right)$. The linear absorption coefficient, $\square$, for Mo-K $\square$ radiation is $7.06 \mathrm{~cm}^{-1}$, and no absorption correction was applied. The data were corrected for Lorentz and polarization effects.

The structure was solved by direct methods and expanded using Fourier techniques. ${ }^{2}$ The non-hydrogen atoms were refined anisotropically, and hydrogen atoms were treated as idealized contributions. The final cycle of full-matrix least-squares refinement ${ }^{3}$ on $\mathrm{F}$ was based on 8560 observed reflections (I > 2.00 $\square(\mathrm{I})$ ) and 488 variable parameters and converged with unweighted and weighted agreement factors of:

$$
\begin{gathered}
\mathrm{R}=\square\|\mathrm{Fol}-|\mathrm{Fc} \| / \square| \mathrm{Fo} \mid=0.0454 \\
\mathrm{R}_{\mathrm{W}}=\left\{\square\left[\mathrm{w}\left(\mathrm{F}_{\mathrm{o}}{ }^{2}-\mathrm{F}_{\mathrm{c}}^{2}\right)^{2}\right] / \square\left[\mathrm{w}\left(\mathrm{F}_{\mathrm{o}}^{2}\right)^{2}\right]\right\}^{1 / 2}=0.1009
\end{gathered}
$$

The maximum and minimum peaks on the final difference Fourier map corresponded to 0.628 and $-0.925 \mathrm{e}^{-} / \AA^{3}$, respectively. 
S25

Figure S7. ORTEP drawing of molecule 3.

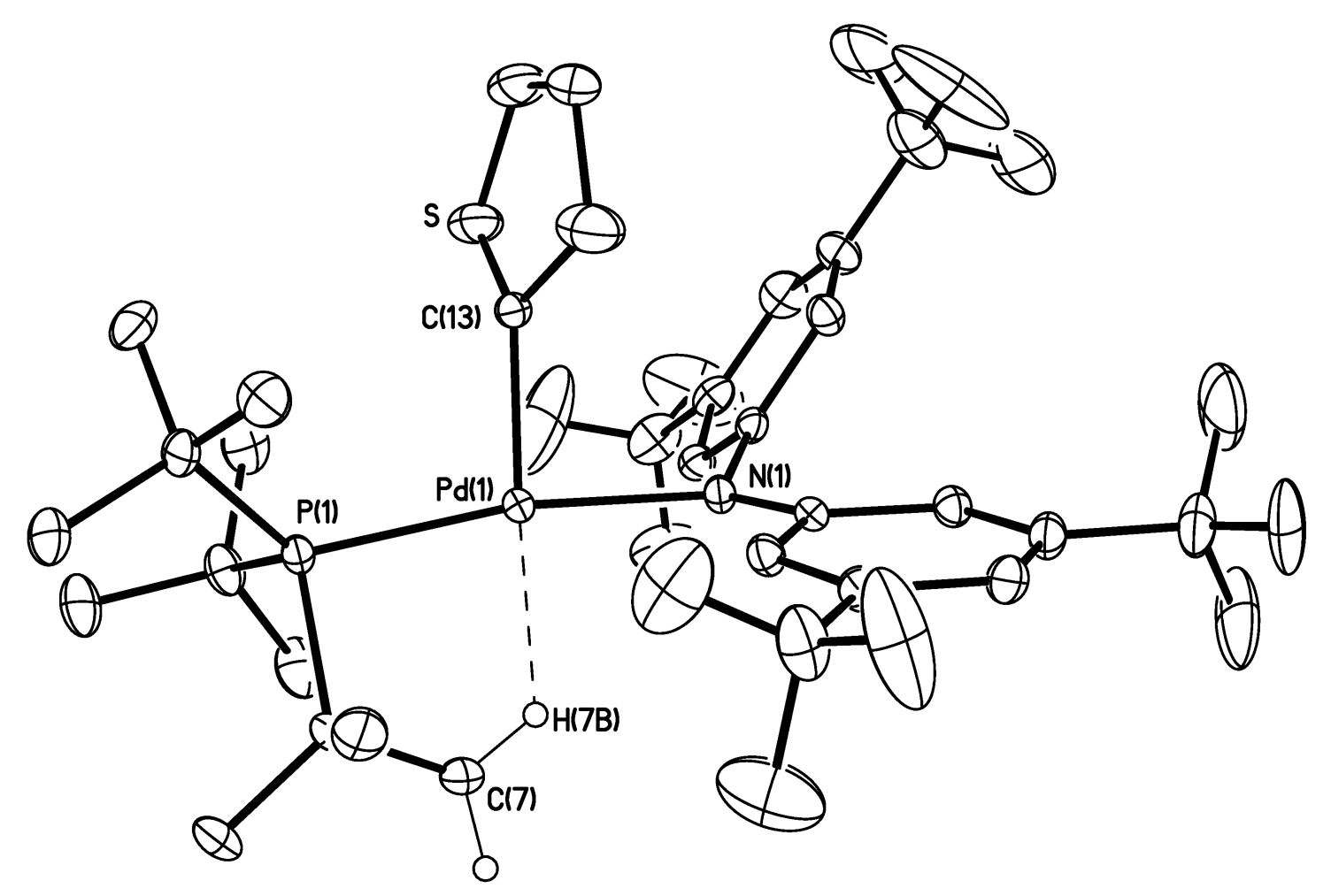


Experimental details for the crystal structure determination of 4.

A yellow block crystal of $\mathrm{C}_{57} \mathrm{H}_{41} \mathrm{~F}_{12} \mathrm{FeNOP}_{2} \mathrm{Pd} \cdot 1.5 \mathrm{C}_{7} \mathrm{H}_{8}, \mathrm{C}_{67.5} \mathrm{H}_{53} \mathrm{~F}_{12} \mathrm{FeNOP}{ }_{2} \mathrm{Pd}$, having approximate dimensions of $0.25 \times 0.25 \times 0.20 \mathrm{~mm}^{3}$ was mounted with epoxy cement on the tip of a fine glass fiber. All measurements were made on a Nonius KappaCCD diffractometer with graphite monochromated Mo-K $\square$ radiation. Cell constants and an orientation matrix for data collection corresponded to a triclinic cell with dimensions:

$$
\begin{array}{llll}
\mathrm{a}= & 13.525(3) \AA & \square=73.57(3)^{\mathrm{O}} \\
\mathrm{b}=15.326(3) \AA & \square=71.97(3)^{\mathrm{o}} \\
\mathrm{c}=15.580(3) \AA & \square= & 81.58(3)^{\mathrm{O}} \\
\mathrm{V}= & 2939.2(10) \AA^{3} & &
\end{array}
$$

For $\mathrm{Z}=2$ and F.W. $=1346.30$, the calculated density is $1.521 \mathrm{~g} / \mathrm{cm}^{3}$. Based on a statistical analysis of intensity distribution, and the successful solution and refinement of the structure, the space group was determined to be: $P-1$ (\#2). The data were collected at a temperature of $173(2) \mathrm{K}$ to a maximum $2 \square$ value of 52.00 ${ }^{\circ}$. Seven omega scans consisting of $37,37,34,29,24,29$, and 7 data frames, respectively, were collected with a frame width of $2.0^{\circ}$ and a detector-to-crystal distance, Dx, of $35.0 \mathrm{~mm}$. Each frame was exposed twice (for the purpose of de-zingering) for a total of 40 seconds. The data frames were processed and scaled using the DENZO software package. ${ }^{1}$

A total of 20270 reflections were collected of which 11466 were unique and observed $\left(\mathrm{R}_{\text {int }}=0.0396\right)$. The linear absorption coefficient, $\square$, for Mo-K $\square$ radiation is $6.91 \mathrm{~cm}^{-1}$, and no absorption correction was applied. The data were corrected for Lorentz and polarization effects.

The structure was solved by direct methods and expanded using Fourier techniques. ${ }^{2}$ The non-hydrogen atoms were refined anisotropically, and hydrogen atoms, with exceptions noted, were treated as idealized contributions. The final cycle of full-matrix least-squares refinement ${ }^{3}$ on $\mathrm{F}$ was based on 11466 observed reflections (I > 2.00 $\square(\mathrm{I})$ ) and 782 variable parameters and converged with unweighted and weighted agreement factors of:

$$
\begin{gathered}
\mathrm{R}=\square\|\mathrm{Fol}-|\mathrm{Fc} \| / \square| \mathrm{Fo} \mid=0.0485 \\
\mathrm{R}_{\mathrm{W}}=\left\{\square\left[\mathrm{w}\left(\mathrm{F}_{\mathrm{o}}^{2}-\mathrm{F}_{\mathrm{c}}^{2}\right)^{2}\right] / \square\left[\mathrm{w}\left(\mathrm{F}_{\mathrm{o}}^{2}\right)^{2}\right]\right\}^{1 / 2}=0.1253
\end{gathered}
$$

The maximum and minimum peaks on the final difference Fourier map corresponded to 1.023 and $-0.671 \mathrm{e}^{-/} \AA^{3}$, respectively. 
Figure S8. ORTEP drawing of molecule 4.

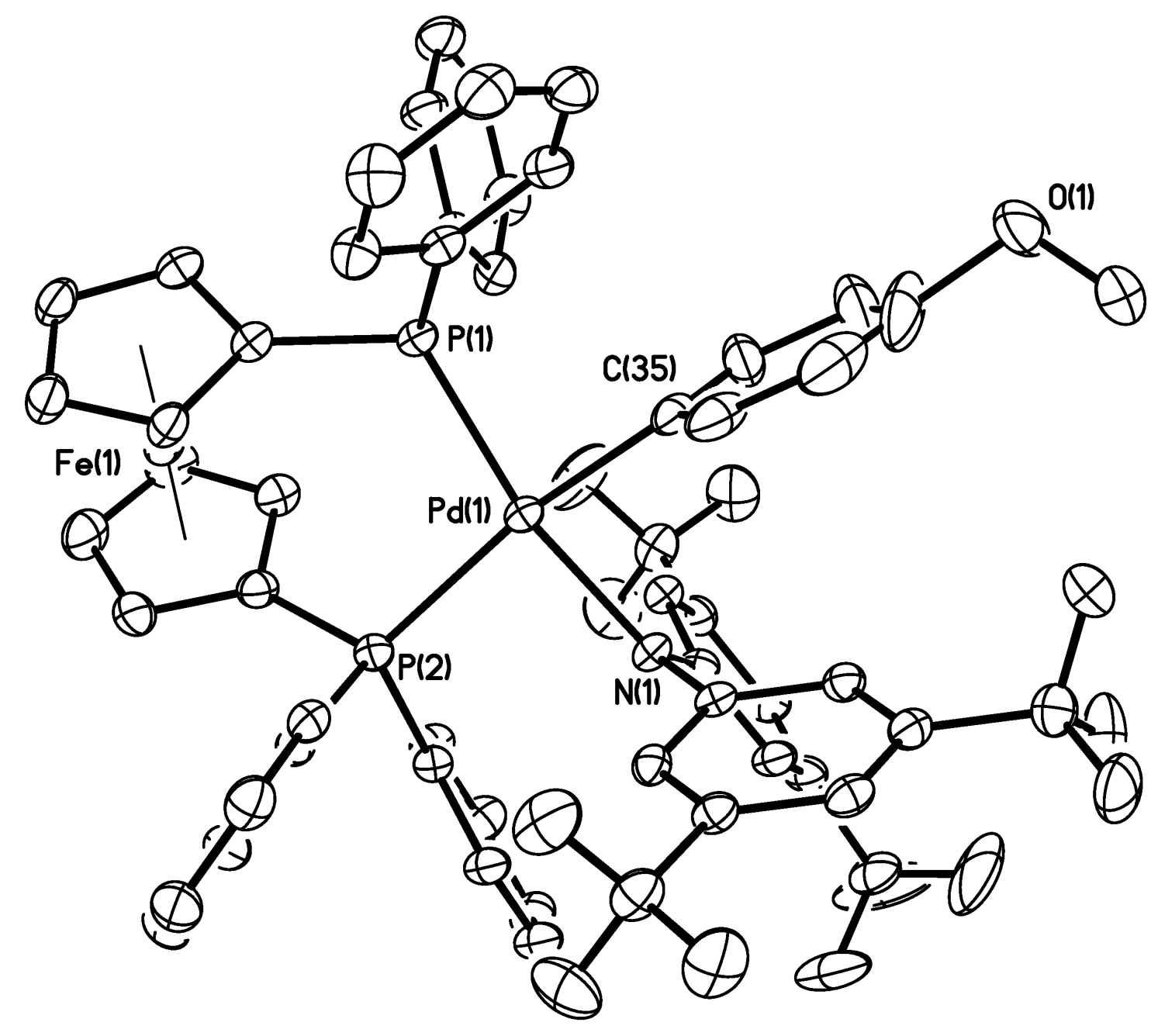




\section{References for Crystallographic Procedures}

(1) Z. Otwinowski and W. Minor, "Processing of X-Ray Diffraction Data Collected in Oscillation Mode," Methods in Enzymology, vol. 276: Macromolecular Crystallography, part A, 307-326, 1997, C.W. Carter, Jr. \& R.M. Sweet, Eds., Academic Press.

(2) Acta Cryst. A46 (1990) 467-473

(3) Least Squares function minimized: $\square w\left(\mathrm{~F}_{\mathrm{o}}{ }^{2}-\mathrm{F}_{\mathrm{c}}{ }^{2}\right)^{2}$ 